Chapter 4

\title{
Managing CNS Tumors: The Nanomedicine Approach
}

\author{
Juan Aparicio-Blanco and Ana-Isabel Torres-Suárez
}

Additional information is available at the end of the chapter

http://dx.doi.org/10.5772/66131

\begin{abstract}
Albeit the rapidly evolving knowledge about tumor biochemistry enables various new drug molecules to be designed as treatments, malignant central nervous system (CNS) tumors remain untreatable due to the failure to expose the entire tumor to such therapeutics at pharmacologically meaningful quantities. Therefore, drug delivery in CNS tumors must be properly addressed, as otherwise, novel therapies will continue to fail. In this regard, nanomedicine poses an appealing platform for efficient drug delivery to the CNS, since it may be targeted to improve the drug availability in the site of action, which would be translated into lower drug doses and fewer side effects. Hence, the accumulation of data about the CNS physiology and their relevant receptors, the widening therapeutic armamentarium of drugs potentially useful in CNS chemotherapy and the alternative routes for administration may envisage nanomedicines as a forthcoming routine approach. Indeed, on the basis of the promising results gathered from preclinical studies of nanomedicine-based therapy both systemically and locally administered, some nanomedicines have already been approved for clinical trials in a variety of CNS tumor conditions to serve as the first steps in the translation of nanotherapy to clinic. Their outcome will steer research directions for further improvements.
\end{abstract}

Keywords: central nervous system tumors, chemotherapy, brain targeting, clinical trials, local delivery, systemic delivery

\section{Introduction}

Primary central nervous system (CNS) tumors represent $2 \%$ of all cancers in adults, whereas this percentage increases to $15-25 \%$ in children. Primary brain tumors are stratified by the World Health Organization (WHO) according to a "malignancy scale". The WHO grade is closely related to clinical prognosis, ranging from grade I (with low proliferative potential and the 
possibility of cure following surgical resection alone) to grade IV (with widespread invasion of the surrounding healthy tissue, high proliferative potential, recurrence and fatal outcome). Unfortunately, many low-gradegliomaseventually often show progression toahigherhistologic grade [1].

Gliomas represent approximately $80 \%$ of all malignant primary brain tumors. Glioblastomas (WHO grade IV) are the most frequent (54.4\%) and aggressive type of glioma [2], although, in terms of treatment, WHO grade III brain tumors and glioblastomas are clustered together and treated similarly.

Although the management of brain tumors depends on the time of diagnosis, new onset or recurrence, the performance status and the age of the patient, the current standard approach in high-grade brain tumors combines maximal surgical resection (if eligible) with radiotherapy and concomitant and adjuvant chemotherapy as well as symptomatic treatment [3].

Available chemotherapy for high-grade brain tumors includes temozolomide, nitrosureas [carmustine (BCNU) and lomustine (CCNU)], topoisomerase inhibitors (etoposide, irinotecan), platinum agents (carboplatin), procarbazine, and vincristine. The first-line chemotherapy for newly diagnosed glioblastoma multiforme consists of temozolomide, whereas carmustine represents the second-line treatment. After the approval of temozolomide in 1999, irinotecan, etoposide, and platinum agents are mostly used only as adjuvant chemotherapy of bevacizumab (FDA approved in 2009 in monotherapy) for recurrent glioblastomas. In the case of WHO grade III gliomas (anaplastic astrocytomas and oligodendrogliomas), the first-line treatment is the PCV (procarbazine-lomustine-vincristine) combination [4].

Unfortunately, the efficacy of the treatment of brain tumors is questionable, since recurrence happens within 6.9 months of initial diagnosis. As a result, despite the combination of surgical resection, radiotherapy and concomitant temozolomide, glioblastoma multiforme remains incurable with a poor median survival of 14.6 months and 2-year survival rate of $26.5 \%$ [5]. This poor prognosis results from chemotherapy tumor resistance [6].

One of the chemoresistance mechanism best characterized relates to the expression of $\mathrm{O}^{6}-$ methylguanine-DNA methyltransferase (MGMT), a repair gene that removes alkyl groups from the $\mathrm{O}^{6}$ position of guanine and consequently counteracts the alkylating agents (temozolomide or nitrosureas). Methylation of the promoter of this gene, which occurs in $35-45 \%$ of the cases, makes glioblastoma more sensitive to alkylating agents $[7,8]$.

Likewise, the existence of glioma stem cells greatly accounts for tumor recurrence, since they upregulate the expression level of P-gycoprotein [9], which is responsible for active efflux of many chemotherapy agents, including temozolomide.

The overexpression of epidermal growth factor receptor (EGFR), which ultimately triggers the activation of complex alternative signaling pathways, aimed at inhibiting apoptosis, also contributes to resistance to standard chemotherapy. Unfortunately, none of the receptor tyrosine kinase inhibitors and signal transduction inhibitors tested in clinical trials prolonged the mean survival, mainly due to the lack of successful drug delivery across the blood-brain tumor barrier (BBTB), since the exposure of the tumor to sublethal drug concentrations helps select the drug-resistant tumor cells [10]. 
The BBTB consists of the endothelium of existing and abnormal angiogenic blood vessels that deliver nutrients and oxygen to the tumor and enable widespread glioma migration to brain areas where the function of the barrier is still intact. Therefore, even though the BBTB is considered dysfunctional, the truth is that in low grade and in the infiltrative parts of highgrade gliomas, often responsible for the recurrence, the BBTB closely resembles the tight bloodbrain barrier (BBB) typical of healthy brain capillaries [11]. Hence, the BBTB greatly accounts for the failure rate of the brain tumor therapy, since the hindrance to brain delivery of chemotherapeutic agents at pharmacologically effective levels conferred by this barrier cannot be offset by dose increase for fear of systemic toxicity. Furthermore, drug efflux pumps of the BBB can also be expressed in endothelium at the BBTB, representing an additional constraint to the achievement of adequate drug levels at the target site [12].

Since the therapeutic potential of chemotherapy greatly depends on its ability to attain pharmacologically effective levels at the entire diseased brain area, novel strategies to enhance drug delivery at the tumor site are strongly needed.

\section{The nanomedicine approach}

Conventional chemotherapy has failed to improve the prognosis of CNS tumors; hence novel drug delivery technologies have emerged under the assumption that targeted drug delivery could contribute to expose the entire tumor to therapeutically meaningful levels and ultimately improve treatment outcomes for brain tumors. An example of the success achievable thanks to advances in pharmaceutical technology is Gliadel ${ }^{\circledR}$, the first FDA-approved brain cancer treatment to deliver chemotherapy directly to the tumor site in patients with malignant glioma for whom surgical resection is indicated. Gliadel ${ }^{\circledR}$ is a biodegradable wafer implanted on the surface of the resected tumor beds at the time of surgery that delivers carmustine steadily for about 3 weeks directly to the tumor site minimizing drug exposure to other areas of the body. Gliadel® contributes to eradicate the residual tumor cells at the resection margin and complements other standard therapies for brain tumors (surgery and radiotherapy) [13].

Nanomedicine represents an encouraging trend within the field of novel drug delivery technology with potential to preferentially delivering the drug at the target site and consequently overcoming biodistribution and pharmacokinetic limitations that eventually account for treatment failure of brain tumors. Nanomedicine is the application of nanotechnology in view of making a medical diagnosis or treating or preventing diseases. It exploits the improved and often novel properties of materials at a nanoscale. Nanomedicines are colloidal structures that act as drug carriers in which the drug substance is dissolved, entrapped, or encapsulated, or to which the drug substance is adsorbed or attached [14]. Unlike monolithic implants such as Gliadel ${ }^{\circledR}$, colloidal carriers can be administered with conventional needles and therefore are not limited to those brain tumors where surgical resection is indicated.

Nanomedicine is especially relevant for chemotherapeutic agents, whose low dose availability at the tumor site cannot be counterbalanced by dose increase for fear of severe systemic side effects. Targeted nanomedicines would improve the availability of the drug at the scattered 
tumor bed and would allow obtaining therapeutic effects with lower drug doses and concomitantly minimizing the side effects of chemotherapy not only in unwanted peripheral tissues, but also in healthy brain cells. Therefore, the therapeutic index of drugs would be greatly enhanced thanks to nanomedicine. Targeted drug delivery to the site of action can be achieved through passive and active targeting or even through external physical stimuli. Passive targeting exploits the specific anatomical and functional features of the target tissues or cells to deliver drugs to the site of action. Active targeting requires the conjugation of tissue or cellspecific ligands on the surface of nanocarriers, whose recognition would eventually allow preferential accumulation of the drug at the diseased site. External stimuli such as a magnetic field, focused ultrasounds, light, and heat can also help selectively release the drug payload of nanomedicines at the target site [15].

Moreover, whereas most anticancer drugs are hydrophobic and often require to be solubilized in organic solvents for conventional administration, nanomedicines provide alternative formulations to administer chemotherapy without the need to use toxic solvents. Furthermore, nanomedicine is opening new therapeutic opportunities for easily degradable drug substances that cannot be used effectively as conventional formulations due to their short half-lives in vivo. Nanomedicines not only shield such drugs from enzymatic and chemical drug cleavage that accounts for the loss of pharmacological effect, but also can sustain and/or trigger drug release at a specific rate at the target site, resulting in maintenance of drug levels within a therapeutically desirable range. Thanks to this controlled release profile, undesirable pharmacokinetic properties of drug substances can be overcome with the use of nanocarriers and the dosing frequency can be improved to prescribe more comfortable dose regimens for patients.

The nanomedicine approach to enhance drug delivery to CNS tumors is highly versatile, since it would allow the coadministration of different anticancer agents and is compatible with both local and systemic routes of administration. In the current scenario, this approach must be directed toward surpassing acquired resistance to conventional chemotherapy and implementing strategies to boost the distribution across the brain endothelium in the case of systemic administration [16].

Nevertheless, nanomedicines might likewise cause unexpected toxicities as the other excipients also reach target tissues along with the drug. Nondegradable nanomedicines used for drug delivery would accumulate at the tumor site and would ultimately result in chronic inflammatory response, because, as colloidal systems, there is no chance of removing them after completion of the treatment. Albeit toxicity concerns of nanomedicines greatly rely on the relatively unexplored size-dependent properties and interaction with biological structures that strikingly differ from those of the bulk material, it is broadly agreed that the safety profile of brain-targeted nanomedicines would be improved with biocompatible excipients devoid of any short or long-term toxic effects [17]. Consequently, despite the large number of available biomaterials for nanomedicines preparation, only a few are suitable for brain tumor treatment because the CNS requires conservative choices with a proven track record of clinical safety. Nanomedicines developed for brain delivery mainly belong to three categories: polymerbased, lipid-based and metal-based, according to their major excipient (Table 1). 


\begin{tabular}{|c|c|c|c|c|}
\hline Category & Nanocarrier & Description & Size $(\mathrm{nm})$ & $\begin{array}{l}\text { Phase of } \\
\text { development }\end{array}$ \\
\hline \multirow[t]{3}{*}{$\begin{array}{l}\text { Polymer- } \\
\text { based }\end{array}$} & $\begin{array}{l}\text { Polymeric } \\
\text { nanoparticles }\end{array}$ & $\begin{array}{l}\text { Solid matrix-like or reservoir-like nanostructures } \\
\text { made up of biocompatible and biodegradable } \\
\text { polymers or copolymers }\end{array}$ & $20-1000$ & Preclinical \\
\hline & $\begin{array}{l}\text { Polymeric } \\
\text { micelles }\end{array}$ & $\begin{array}{l}\text { Nanostructures of amphiphilic diblock copolymers } \\
\text { with a core of hydrophobic blocks stabilized by a } \\
\text { corona of hydrophilic blocks }\end{array}$ & 50-200 & Preclinical \\
\hline & Dendrimers & $\begin{array}{l}\text { Highly branched tree-like nanostructures composed } \\
\text { of a central core, internal branches, and reactive } \\
\text { terminal groups }\end{array}$ & $1-10$ & Preclinical \\
\hline \multirow[t]{3}{*}{ Lipid-based } & Liposomes & $\begin{array}{l}\text { Vesicles of amphipathic lipids structured in } \\
\text { concentric bilayers surrounding an equal number } \\
\text { of central aqueous compartments }\end{array}$ & $80-200$ & $\begin{array}{l}\text { Phase I, II clinical } \\
\text { trials }\end{array}$ \\
\hline & $\begin{array}{l}\text { Solid lipid } \\
\text { nanoparticles }\end{array}$ & $\begin{array}{l}\text { Solid lipid matrixes at room and body temperatures } \\
\text { that are stabilized by surfactant(s) }\end{array}$ & 50-1000 & Preclinical \\
\hline & $\begin{array}{l}\text { Lipid } \\
\text { nanocapsules }\end{array}$ & $\begin{array}{l}\text { Reservoir nanomedicines with a liquid oily core, } \\
\text { surrounded by a shell of surfactants }\end{array}$ & 20-100 & Preclinical \\
\hline \multirow[t]{2}{*}{ Metal-based } & $\begin{array}{l}\text { Magnetic } \\
\text { nanoparticles }\end{array}$ & $\begin{array}{l}\text { Nanostructures composed of magnetic elements that } \\
\text { can be manipulated using magnetic fields }\end{array}$ & $10-50$ & Preclinical \\
\hline & $\begin{array}{l}\text { Gold } \\
\text { nanoparticles }\end{array}$ & $\begin{array}{l}\text { Nanostructures that can serve as drug carriers and } \\
\text { even convert absorbed electromagnetic radiation to } \\
\text { heat }\end{array}$ & $5-50$ & Preclinical \\
\hline
\end{tabular}

Table 1. Main types of nanomedicines that are currently under investigation for the treatment of CNS tumors.

Overall, lipid-based nanomedicines may well be the most suitable for CNS drug delivery; insofar as lipids have very low toxicity, are biocompatible and biodegradable by nature, and the commercially available lipid-based formulations show a solid track record of clinical safety [18-20], whereas at present, only a few of the studied polymers for the development of polymer-based nanomedicines for brain drug delivery have demonstrated biocompatible, biodegradable, and nontoxic properties to be approved by the FDA for clinical use [21-23]. On the other hand, since the lack of biodegradation may not be appropriate for long-term administration, most metal-based nanomedicines (such as magnetic nanoparticles and gold nanoparticles) have been made more biocompatible and water-soluble with polymer coating [24].

\section{Local delivery of nanomedicines}

The local delivery of anticancer drugs serves to overcome the lack of specificity of conventional chemotherapy. Higher drug levels at the tumor site and lower drug distribution to healthy tissues account for the reduction of the systemic side effects with local routes of administration. Moreover, in the case of CNS tumors, local chemotherapy bypasses the major hurdle for systemic brain drug delivery: the blood-brain tumor barrier. However, the mechanical breach of this barrier may act as a double-edged sword since this might allow neurotoxic blood components to enter the brain or even enhance tumor dissemination. 
Nanomedicines offer several advantages over conventional chemotherapy with regard to local CNS delivery: they can extend the exposure to short-brain-half-life drugs and provide longlasting drug release that ultimately maintains therapeutic levels at the target site over longer periods. Moreover, nanomedicines show potential for enhancing antitumor activity via several pathways. First, locally administered nanomedicines can promote passive diffusion of the anticancer agent to the brain tumor tissue by increasing the local drug concentration gradient. Furthermore, nanomedicines can be actively targeted to the brain tumor cells by conjugating specific ligands that bind to the receptors that are overexpressed or uniquely expressed on the tumor surface (a mutant form of the epidermal growth factor receptor (EGFRvIII), interleukin receptors for interleukins 4 and 13) to efficiently trigger cellular uptake at the tumor site.

Similarly, locally administered nanomedicines can also help overcome some of the most troublesome chemoresistance mechanisms that are eventually responsible for tumor recurrence. In this sense, the upregulated expression of P-glycoprotein in drug-resistant cancer stem cells, which accounts for active efflux of most anticancer agents from the tumor area and reduces the effectiveness of chemotherapy, can be overcome thanks to nanomedicine. Indeed, the coating with nonionic surfactants seems to confer the nanocarrier itself with efflux-pump blockage properties [25]. Additionally, along with chemotherapy, nanomedicines can serve to deliver irreversible MGMT inhibitors (such as $\mathrm{O}^{6}$-benzylguanine) and/or receptor tyrosine kinase inhibitors, to sensitize brain tumor cells to alkylating agents, and to counteract the inhibition of apoptosis mediated by the overexpression of the receptor of the epidermal growth factor (EGFR), respectively.

Several local routes of administration may be exploited by nanomedicines for handling of CNS tumors.

- The intracranial administration involves drug delivery directly into the brain parenchyma. Nonetheless, intraoperative infusion of anticancer drugs into brain tumors has experienced minor success given the diffusion-limited drug distribution, which does not allow the drug to reach the infiltrative area of recurrence. Moreover, the high interstitial fluid pressure and the presence of edema often observed in intracranial tumors may further hinder the diffusion of the infused agent.

Alternatively, convection-enhanced delivery (CED), another method for intracranial administration, achieves larger distribution volumes in the brain, for more homogeneous distribution within the tumor tissue, since it uses positive pressure to supplement simple diffusion with fluid convection. CED continuously delivers a bulk flow under a pressure gradient via a stereotactically guided catheter connected to a syringe pump. Drug leakage away from the tumor site [especially into the subarachnoid space with the subsequent drug spreading via the circulating cerebrospinal fluid (CSF)] should be avoided to minimize side effects such as chemical meningitis. In this regard, the suitable placement of catheters often prevents the leakage and helps spare healthy tissue.

CED can likewise deliver nanocarriers loaded with antineoplastic agents for CNS tumor therapy [26]. When combined with CED, the encapsulation of the drug infused into nanocarriers further reduces the potential side effects caused by drug leakage, while extends the brain 
half-life of anticancer agents by preventing them from being rapidly metabolized and/or eliminated by capillaries from the injection site. However, for efficient CED through the brain interstitium, the physicochemical properties of the colloidal systems must be optimized.

First, CED-injected nanomedicines must diffuse through interstitial spaces of the brain tissue. Hence, the size of the colloidal systems is a critical parameter to achieve optimal distribution volume with full coverage of the brain tumor tissue. Particles larger than $100 \mathrm{~nm}$ do not move readily through the brain interstitium, are retained near the administration site and do not distribute over clinically relevant volumes of brain tissue. Hence, in terms of size, the ideal nanocarrier for CED should be about $20-50 \mathrm{~nm}$.

Moreover, to achieve optimal distribution volumes to cover both the tumor bed and the outlying cancer stem cells, it is convenient to provide nanocarriers with a hydrophilic coating [mostly polyethylene glycol (PEG) [27]]. The hydrophilic coating could help mask the hydrophobic structures, which would reduce the eventual binding to brain cells or to proteins in the interstitial space and ultimately enable greater diffusion. However, hydrophilic coating of nanocarriers also has the drawback of reducing the interactions with tumor cells, required for the loaded anticancer drug to eradicate the tumor. Alternatively, distribution volumes can be enhanced with the presence of co-infusates that serve to saturate the potential binding sites along the track of the infused nanomedicines. Furthermore, the ideal CED-administered nanocarrier should have a global neutral or negative charge to prevent nonspecific binding to negatively charged structures in the brain parenchyma and to achieve larger distribution volumes [27].

In addition, the infusion of viscous and hyperosmolar suspensions of nanocarriers would help reduce the risk of drug leakage and enhance the distribution volume by means of osmosismediated dilatation of the interstitial space through which nanocarriers could transit, respectively.

Nonetheless, despite its remarkable potential to improve clinical outcomes for CNS tumors, intracranial CED is an invasive neurosurgical procedure, which truly hinders its widespread use and limits the number of dosing cycles to be applied to eligible patients.

- The intrathecal administration involves the injection of anticancer drugs into the intrathecal space, which is the space that holds the cerebrospinal fluid (CSF). This can be achieved either with the implantation of an Ommaya reservoir (a dome-shaped container that is placed subcutaneously under the scalp during surgery, holds the chemotherapy and delivers it into the cerebral ventricles through a small catheter) or with direct injection into the CSF through a numbed area of the lower part of the spinal cord. Despite the significantly less invasive character of the second approach, intrathecal delivery fails to accumulate drugs in the brain parenchyma due to the bulk flow rate of CSF into the venous system, making this route optimal for the treatment of spinal tumors and disseminated meningeal metastases but not for parenchymal tumors like glioblastoma. Indeed, since meningeal gliomatosis remain protected by the blood-brain barrier, intrathecal delivery is widely considered a treatment approach for achieving improved outcomes for these patients [28]. 


\begin{tabular}{|c|c|c|c|c|}
\hline Encapsulated drug & System & Model & $\begin{array}{l}\text { Route of } \\
\text { administration }\end{array}$ & References \\
\hline Irinotecan & Liposomes & U87-bearing rats & CED & [30] \\
\hline Irinotecan & Liposomes & GBM43-/SF7796-bearing mice & CED & [32] \\
\hline Topotecan & Liposomes & U251-/U87MG-bearing rats & CED & {$[31,36]$} \\
\hline Topotecan + Doxorubicin & Liposomes & U87MG-bearing rats & CED & [33] \\
\hline Irinotecan + Doxorubicin & Liposomes & U251-/U87MG-bearing rats & CED & {$[34]$} \\
\hline Camptothecin & Polymer nanoparticles & 9L-bearing rats & CED & {$[46]$} \\
\hline Temozolomide & Polymer nanoparticles & U87-bearing rats & CED & [47] \\
\hline $\begin{array}{l}\text { HSVtk } \\
\text { (+ intraperitoneal } \\
\text { Ganciclovir) }\end{array}$ & $\begin{array}{l}\text { Polymeric } \\
\text { nanoparticles }\end{array}$ & 9L-bearing rats & CED & {$[48]$} \\
\hline $\begin{array}{l}\text { Paclitaxel } \\
\text { (+ radiotherapy) }\end{array}$ & Lipid nanocapsules & 9L-bearing rats & CED & {$[49]$} \\
\hline Ferrociphenol & Lipid nanocapsules & 9L-bearing rats & CED & {$[37,38,50]$} \\
\hline $\begin{array}{l}\text { Ferrociphenol (+ } \\
\text { radiotherapy) }\end{array}$ & Lipid nanocapsules & 9L-bearing rats & CED & [51] \\
\hline Metothrexate & $\begin{array}{l}\text { Fifth-generation } \\
\text { dendrimers }\end{array}$ & F98-bearing rats & CED & [42] \\
\hline Cisplatin & $\begin{array}{l}\text { Fifth-generation } \\
\text { dendrimers }\end{array}$ & F98-bearing rats & CED & {$[43]$} \\
\hline EGFRvIII antibody & Magnetic nanoparticles & U87 glioma-bearing mice & CED & {$[39]$} \\
\hline Cetuximab & Magnetic nanoparticles & $\begin{array}{l}\text { NO8-30, U87 and LN229- } \\
\text { bearing mice }\end{array}$ & CED & [40] \\
\hline $\begin{array}{l}\text { O6-Benzylguanine } \\
\text { (+ oral temozolomide) }\end{array}$ & Magnetic nanoparticles & GBM6-bearing mice & CED & {$[35]$} \\
\hline Doxorubicin & Polymeric micelles & 9L gliosarcoma-bearing rats & CED & {$[41]$} \\
\hline $\begin{array}{l}\text { Synthetic retinoid Am80 } \\
\text { (+ intraperitoneal } \\
\text { temozolomide) }\end{array}$ & Polymeric micelles & U87 glioma-bearing rats & CED & {$[52]$} \\
\hline Camptothecin & Polymeric micelles & C6 glioma-bearing rats & Intranasal & {$[44]$} \\
\hline $\begin{array}{l}\text { Camptothecin + siRNA } \\
(\text { Raf-1) }\end{array}$ & Polymeric micelles & C6 glioma-bearing rats & Intranasal & {$[45]$} \\
\hline
\end{tabular}

Table 2. Locally-administered nanomedicines already tested for efficacy in vivo against orthotopic rodent brain tumor models.

Unfortunately, not all anticancer agents are suitable for intrathecal delivery, as drug spread along the spinal canal can cause dose-limiting chemical arachoniditis. For those irritant drug substances, intrathecal delivery can take great advantage of nanomedicine, since their encapsulation into nanostructures could minimize drug exposure to toxic levels. As a proof of 
it, intrathecal-administered liposomal cytarabine (Depocyt@) has been approved for clinical use in lymphomatous meningitis. Nonetheless, the cytotoxicity of cytarabine against a wide spectrum of tumors makes Depocyt ${ }^{\circledR}$ a promising candidate for treating the above-mentioned forms of CNS cancer.

- More recently, the intranasal delivery has been proposed as an alternative local route of administration. Its noninvasive nature would allow self-administration by nasal inhalation and would enable the sterilization procedures of the drug dosage form to be avoided. This delivery route exploits the fact that trigeminal and olfactory nerves that innervate the nasal epithelium represent the only direct connection between the external environment and the brain [29]. However, this route appears to be relatively inefficient in delivering inhaled drugs to distant brain structures, mainly due to drug loss via systemic absorption.

In regard to brain tumor therapy, intranasal administration has received minor attention, with most applications of this approach being focused on the treatment of neurodegenerative diseases.

Numerous locally administered drug-loaded nanomedicines have already been assayed for efficacy in rodent models of brain tumors: liposomes, polymer nanoparticles, lipid nanocapsules, dendrimers, magnetic nanoparticles, and polymeric micelles, as summarized in Table 2. Although results are highly variable depending on various parameters, namely the tumor lineage and the onset, dose, and regimen of treatment, some general conclusions can be drawn from these preclinical studies. Overall, liposomes exhibited the most noticeable survival benefit and the presence of the highest percentage of long-term survivors [30, 31], partly because their potential as drug carriers was acknowledged earlier than any other alternative nanomedicine; hence research on nanomedicines for local CNS anticancer therapy has largely focused on liposomes.

Likewise, in some preclinical studies in rodent models, it was even evidenced that CED outperformed the survival benefit of the same formulation administered by a peripheral intravascular route [32]. Furthermore, the versatility of CED has enabled the coadministration of different liposomal formulations to enhance the effect of the anticancer agents [33, 34]. Concerning CED, numerous nanomedicines were formulated with a hydrophilic coating of polyethylene glycol and administered as slightly viscous suspensions to achieve optimal distribution volumes that cover the whole brain tumor tissue [35]. In fact, the deprivation of the hydrophilic coating, albeit increased median overall survival in comparison with untreated controls, significantly differed from efficacy findings reported for animals receiving the pegylated nanomedicines [36]. Nevertheless, it has been postulated the existence of a "threshold extent of pegylation," over which the hindrance conferred by polyethylene glycol to interact with the tumor cells counterbalances the increase in CED distribution volume provided by slight pegylation [37]. On the other hand, the addition of active targeting moieties that preferentially bind to receptors that are overexpressed on brain tumor cells to promote the delivery of nanomedicines to their target cells is controversial: whereas the attachment of OX26 or a cell-penetrating peptide has shown to enhance both tumor and healthy tissue internalization, which led to the appearance of side effects and high morbidity [38], the attachment of chlorotoxin or antibodies that selectively bind to the epidermal growth factor 
receptor mutant (EGFRvIII) present on human glioblastoma cells achieved significant survival benefits $[35,39,40]$. The different response could be explained by the choice of the ligand: ligands that preferentially bind to receptors on the cerebral endothelium are pointless in local delivery, whereas ligands that bind to receptors overexpressed on the brain tumor cells are those to be used for active targeting in local delivery.

Moreover, some studies [41-43] evidenced the importance of an adequate drug release to achieve a therapeutic response: the covalent linkage of methotrexate [42] and cisplatin [43] to dendrimer structures did not lead to any improvement in the median survival time of F98bearing rats due to a release failure, while the survival benefit achieved with micellar doxorubicin in 9L-bearing rats was significantly relevant compared with CED of liposomal doxorubicin at the same dose due to the lack of release of doxorubicin from the liposomal formulation [41].

Importantly, CED-administered nanocarriers have been designed to overcome the MGMTrelated chemoresistance to alkylating agents. $\mathrm{O}^{6}$-benzylguanine has been loaded in iron oxide nanoparticles provided with a biocompatible chitosan-polyethylene glycol coating and actively targeted by chlorotoxin. The concurrent CED administration of these magnetic nanoparticles with oral temozolomide in mice implanted with a GBM6 clinically relevant xenograft extended by twofold the survival times in comparison with mice treated without the MGMT inhibitor and greatly mitigated the severe myelosuppression associated with systemic administration of free $\mathrm{O}^{6}$-benzylguanine [35].

With regard to intranasal administration, polymeric micelles are the only nanomedicine type tested in rodent brain tumor models [44, 45]. The attachment of the cell-penetrating peptide Tat on their surface for actively enhancing the penetration rate across the nasal epithelium extended survival times [44].

\section{Systemic delivery of nanomedicines}

Thanks to the high brain perfusion rate, systemic intravascular administration is a very convenient strategy in the clinical management of cancer for compatibility with repeated drug administration and for its lower invasiveness in comparison with most local delivery routes. However, despite being considered disrupted to some extent, the presence of the BBTB has motivated the failure of conventional systemic chemotherapy for CNS tumors, since in low grade and along the infiltrating areas of high-grade gliomas where recurrences tend to occur, the BBTB closely resembles the nonfenestrated endothelial cells typical of healthy brain capillaries. Hence, the BBTB restricts the paracellular permeation of most anticancer agents into the CNS. As a result, conventional systemic chemotherapy must be administered at high drug doses, which causes severe dose-dependent side effects in healthy nontarget tissues.

Against this background of hindrance to brain tumor delivery, nanomedicine may enhance the distribution of poorly brain-distributed anticancer agents across the brain endothelium, since nanocarriers may well serve to target brain tumors through passive and active targeting or 
even through external physical stimuli [53]. Passive targeting occurs with the diffusion of nanomedicines through the interendothelial gaps of the highly vascularized leaky BBTB in the case of high-grade brain tumors, a phenomenon known as the enhanced retention and permeation (EPR) effect [54]. Moreover, surface-modified brain actively targeted nanomedicines may also enhance CNS delivery across the intact brain endothelium of infiltrative parts and low-grade brain tumors by triggering transcytosis either by ligand-receptor binding or by electrostatic interactions [55]. Therefore, nanomedicines can be useful for the treatment of different malignancy grades of brain tumors. In addition, the use of stimulus-sensitive groups to control drug release within the brain in a therapeutically relevant concentration could further enhance the specificity of the treatment effect to the brain tumor area. Alternatively, nanomedicines can block the active drug efflux back into the bloodstream.

For optimal passive targeting of brain tumors, systemic nanomedicines should have sufficient circulation time [56] to take advantage of the hypervascularized, leaky, and compromised lymphatic drainage system in a CNS tumor and selectively accumulate in the tumor tissue through the EPR effect. When given intravascularly, the larger the nanomedicines, the more susceptible to opsonization and removal by cells of the reticuloendothelial system (RES) [57]. Hence, to reduce opsonization in plasma and increase their plasma circulation time, the size of nanomedicines should be maintained below 100-200 nm. Additionally, the surface coating with hydrophilic polymers such as polyethylene glycol (PEG) to develop "stealth" nanomedicines creates a hydration layer that prevents protein adsorption and evades RES clearance [58], and consequently prolongs their circulation half-life.

Therefore, if properly designed, nanomedicines could cross the leaky BBTB in highly malignant brain tumors by passive targeting. Moreover, the BBTB can be artificially further disrupted to enable a wider distribution of nanomedicines to the brain tumor site. This disruption can be achieved via infusion of a hyperosmotic solution [59] or through the administration of vasoactive agents [60]. Hyperosmotic mannitol infusions cause a transient shrinkage of cerebrovascular endothelial cells, resulting in an enlargement of the tight junctions and BBTB leakiness. However, mannitol infusions also increase the permeability of healthy brain tissue, thereby increasing the risk of neurotoxicity. Conversely, the tumor vasculature is more sensitive than healthy brain vasculature to infusions with vasoactive agents (leukotrienes, bradykinin, and RMP-7, an analogue of bradykinin) through the transient activation of B2 receptors. Nevertheless, delivery of vasoactive agents requires intraarterial infusion, which increases the invasiveness of the procedure, and thereby creates a barrier for clinical translation of this approach. Alternatively, a local, transient, and reversible disruption of the BBTB can be generated by low-frequency focused ultrasound without permanent neuronal injury or other undesired long-term effects [61]. However, the artificial transient disruption of the BBTB is increasingly being considered undesirable since this might lead to widespread tumor dissemination and/or to the development of seizures due to the overexposure to neurotoxic blood components that enter the brain.

Additionally, optimal active targeting of nanomedicines would enable anticancer agents to be delivered across fully functional BBB of infiltrative areas and low-grade brain tumors exploiting carrier-mediated transportation, receptor-mediated, or adsorption-mediated transcytosis. 
On the one hand, the carrier- and receptor-mediated active targeting involves functionalizing the surface of nanomedicines with moieties that specifically bind to receptors overexpressed on the brain endothelium and/or brain tumor cell membranes [62]. Therefore, different receptors in the brain could be employed:

- Penetration into the brain tumor area can be improved by simply targeting receptors that are normally overexpressed on the brain endothelium (such as transferrin receptors, nicotinic acetylcholine receptors, low-density lipoprotein receptor (LRP1), or carriers responsible for brain nutrient uptake) [62]. To target the transferrin receptor, both physiological ligands (transferrin and lactoferrin) and monoclonal antibodies (OX26 and 8D3) have been attached onto the surface of different types of nanomedicines [63-65]. Overall, physiological ligands ensure biocompatibility and nonimmunogenicity but develop competitive phenomena with endogenous ligands, whereas monoclonal antibodies prevent competitive phenomena with endogenous ligands since they bind to a different epitope. Likewise, nicotinic acetylcholine receptors have been targeted with peptides derived from snake neurotoxins, namely candoxin and Ophiophagushannah toxin b [66-68]. The peptide angiopep-2 has also been attached onto the surface of several nanomedicines to target LRP1 [69, 70]. Furthermore, glucose or mannose conjugation to nanomedicines has conferred brain-targeting properties through overexpressed facilitative glucose transporters [71, 72].

- Receptors distributed on proliferating endothelial cells in the tumor vasculature $(\alpha \mathrm{V} \beta 3$ integrin, aminopeptidase $\mathrm{N}$, nucleolin) represent additional potential sites for active targeting of nanomedicines to brain tumor tissue. In this sense, peptides containing the amino acid sequence Arg-Gly-Asp (RGD) have been coupled to the surface of distinct nanomedicines to bind to $\alpha \mathrm{V} \beta 3$ integrin [73, 74]. Another tripeptide Asn-Gly-Arg (NGR) has been conjugated to different nanomedicines to target aminopeptidase N (CD 13) [75]. Moreover, the ability of the F3 peptide and the AS1411 aptamer to bind to nucleolin has been exploited to actively target nanomedicines to the brain tumor tissue $[76,77]$.

- Nanomedicines could also incorporate targeting moieties that bind to receptors that are overexpressed on tumor cells, to reduce the side effects of the antitumor agent on healthy brain cells after bypassing the BBTB. Apart from the already mentioned LRP1 and $\alpha \mathrm{V} \beta 3$ integrin, these tumor targets include the receptor of the epidermal growth factor (EGFR) and its malignant isoform EGFRvIII, receptors for interleukins 13 (IL-13R $\alpha 2$ ) and 4 (IL-4R), the folate and the insulin receptors, and even the membrane-bound matrix metalloproteinase- 2 (MMP-2). Consequently, antibodies to EGFR or EGFRvIII have been conjugated to several nanomedicines for brain tumor targeting. Likewise, antiIL13R $\alpha 2$ antibodies and IL-13 or IL-4derived peptides (PEP-1 or AP-1, respectively) have been attached onto the surface of nanomedicines to selectively bind to interleukin receptors $[78,79]$. To target the folate receptor, folid acid has been used, whereas to target the insulin receptor, the monoclonal antibody 83-14 has been incorporated to nanomedicines, since the use of the physiological ligand in this case was truly restricted by its biological effect on nontarget regions (namely hypoglycemia) [63]. Furthermore, MMP-2 has been widely targeted with nanomedicines coupled to a peptide derived from scorpion venom: chlorotoxin $[65,80]$. 
Since any ligand for which a receptor exists on the cerebral endothelial or on the tumor cells might be used for active targeting, the enrichment of knowledge about the transport systems present on the BBB/BBTB and the glioma-specific receptors would enable novel practical approaches for improving the passage of nanomedicines to be designed with the purpose of exposing the entire diseased brain tumor area to pharmacologically meaningful quantities.

On the other hand, the adsorption-mediated active targeting takes advantage of electrostatic interactions between positively charged ligands and the negatively charged sialic acid residues in membrane glycoproteins of brain endothelial cells to trigger transcytosis. Hence, this type of active targeting involves modifying the surface of nanomedicines to make them positively charged, namely functionalization with cationic serum albumin and cell-penetrating peptides. The most frequently used cell-penetrating peptide for functionalization of nanomedicines is the transactivator of transcription peptide derived from HIV (TAT).

Subsequently, nanomedicines can also be designed to target simultaneously the BBB, the BBTB and the brain tumor cells by either attaching multiple targeting moieties, or by conjugating a single ligand that targets both the brain endothelia and the brain tumor cells [81]. In this case, nanomedicine could indeed represent a potential platform for targeting heterogeneous brain tumors [15].

Finally, nanomedicines can increase intratumoral concentration of systemically administered anticancer agents by inhibiting the efflux pump function of P-glycoprotein that is present at the BBTB and at the infiltrative tumor cells and that actively removes these drugs, accounting to a great extent for resistance to chemotherapy. A localized inhibition on brain efflux transporters can be achieved by co-loading pharmacological efflux pump inhibitors (such as tamoxifen) or by the nanomedicine itself, since the coating with nonionic surfactants seems to provide the nanocarrier itself with efflux-pump blockage properties.

Besides tailoring the size and surface properties of nanomedicines to influence intratumoral accumulation, external forces such as a magnetic field, light, and heat can also help selectively release the loaded drug of systemically administered nanomedicines at the tumor site [82]. Magnetic targeting has been applied under the assumption that magnetic nanoparticles can accumulate within a tumor area after systemic administration with a locally applied magnetic field. Another external force such as heat can be also used to control drug release in the case of nanomedicines whose excipients exhibit thermosensitive properties. Apart from enhancing tumor blood flow and vascular permeability, the application of local hyperthermia enables the drug to be easily released from thermosensitive nanomedicines when heating over the phasetransition temperature of the excipients.

Numerous intravenously administered drug-loaded nanomedicines have already been assayed for efficacy in rodent models of brain tumors: liposomes, polymer nanoparticles, lipid nanocapsules, dendrimers, polymeric micelles, magnetic nanoparticles, and gold nanoparticles (Table 3). Albeit results extremely depend on the tumor lineage and the onset, dose, and regimen of treatment, some general conclusions can be drawn. In broad terms, following intravenous administration, similar results were obtained with most types of nanomedicines. 


\begin{tabular}{|c|c|c|c|c|}
\hline $\begin{array}{l}\text { Encapsulated } \\
\text { drug }\end{array}$ & System & Strategy & Model & References \\
\hline Paclitaxel & Liposomes & None & 9L gliosarcoma-bearing rats & [89] \\
\hline Paclitaxel & Liposomes & $\begin{array}{l}\text { - Polyethylene glycol coating } \\
\text { - RGD peptide } \\
\text { - Histidine rich TH peptide }\end{array}$ & C6 glioma-bearing mice & [73] \\
\hline Irinotecan & Liposomes & - Polyethylene glycol coating ${ }^{a}$ & $\begin{array}{l}\text { U87MG glioblastoma- } \\
\text { bearing mice }\end{array}$ & [90] \\
\hline Topotecan & Liposomes & $\begin{array}{l}\text { - Polyethylene glycol coating } \\
\text { - Wheat germ agglutinin } \\
\text { - Tamoxifen }\end{array}$ & C6 glioma-bearing rats & [91] \\
\hline Topotecan & Liposomes & - Polyethylene glycol coatinga & $\begin{array}{l}\text { U87M/GBM-43/GBM-6 } \\
\text { glioblastoma-bearing mice }\end{array}$ & [92] \\
\hline Doxorubicin & Liposomes & $\begin{array}{l}\text { - Polyethylene glycol coating } \\
\text { - Folate } \\
\text { - Transferrin } \\
\text { b }\end{array}$ & C6 glioma-bearing rats & [93] \\
\hline Doxorubicin & Liposomes & $\begin{array}{l}\text { - Lactoferrin }{ }^{\mathrm{b}} \\
\text { - Nanocarrier cationization }\end{array}$ & C6 glioma-bearing rats & [94] \\
\hline Doxorubicin & Liposomes & $\begin{array}{l}\text { - Polyethylene glycol coating } \\
\text { - }{ }^{\mathrm{D}} \mathrm{CDX} \text { peptide }\end{array}$ & $\begin{array}{l}\text { U87MG glioblastoma- } \\
\text { bearing mice }\end{array}$ & [66] \\
\hline Doxorubicin & Liposomes & $\begin{array}{l}\text { - Polyethylene glycol coating } \\
\text { - AP-1 peptide } \\
\text { - Focused ultrasound }\end{array}$ & $\begin{array}{l}\text { GBM8401 glioblastoma- } \\
\text { bearing mice }\end{array}$ & [79] \\
\hline Doxorubicin & Liposomes & $\begin{array}{l}\text { - Polyethylene glycol coating } \\
\text { - Glutathione }\end{array}$ & $\begin{array}{l}\text { U87MG glioblastoma- } \\
\text { bearing mice }\end{array}$ & [86] \\
\hline Doxorubicin & Liposomes & $\begin{array}{l}\text { - Polyethylene glycol coating } \\
\text { - Hyperthermia }\end{array}$ & C6 glioma-bearing mice & [95] \\
\hline Epirubicin & Liposomes & $\begin{array}{l}\text { - Polyethylene glycol coating } \\
\text { - Transferrin } \\
\text { - Tamoxifen }\end{array}$ & C6 glioma-bearing rats & [96] \\
\hline Daunorubicin & Liposomes & $\begin{array}{l}\text { - Polyethylene glycol coating } \\
\text { - Mannose } \\
\text { - Transferrin } \\
\text { - }\end{array}$ & C6 glioma-bearing rats & [72] \\
\hline RNA antiEGFR & Liposomes & $\begin{array}{l}\text { - Polyethylene glycol coating } \\
\text { - } 83-14^{\mathrm{b}} \\
-8 \mathrm{D} 3^{\mathrm{b}}\end{array}$ & $\begin{array}{l}\text { U87MG glioblastoma- } \\
\text { bearing mice }\end{array}$ & {$[63]$} \\
\hline siRNA antiEGFR & Liposomes & $\begin{array}{l}\text { - Polyethylene glycol coating } \\
\text { - T7 peptide }\end{array}$ & $\begin{array}{l}\text { U87MG glioblastoma- } \\
\text { bearing mice }\end{array}$ & [64] \\
\hline DNA (pC27) & Liposomes & $\begin{array}{l}\text { - Polyethylene glycol coating } \\
\text { - OX26 } \\
\text { - Chlorotoxine }\end{array}$ & C6 glioma-bearing rats & [65] \\
\hline
\end{tabular}




\begin{tabular}{|c|c|c|c|c|}
\hline $\begin{array}{l}\text { Encapsulated } \\
\text { drug }\end{array}$ & System & Strategy & Model & $\overline{\text { References }}$ \\
\hline Paclitaxel & $\begin{array}{l}\text { Polymeric } \\
\text { nanoparticles }\end{array}$ & $\begin{array}{l}\text { - Polyethylene glycol coating } \\
\text { - AS1411 aptamer }\end{array}$ & C6 glioma-bearing rats & [77] \\
\hline Paclitaxel & $\begin{array}{l}\text { Polymeric } \\
\text { nanoparticles }\end{array}$ & $\begin{array}{l}\text { - Polyethylene glycol coating } \\
\text { - Peptide } 22^{\mathrm{b}}\end{array}$ & C6 glioma-bearing mice & [87] \\
\hline Paclitaxel & $\begin{array}{l}\text { Polymeric } \\
\text { nanoparticles }\end{array}$ & $\begin{array}{l}\text { - Polyethylene glycol coating } \\
\text { - F3 peptide }\end{array}$ & C6 glioma-bearing mice & {$[76]$} \\
\hline Paclitaxel & $\begin{array}{l}\text { Polymeric } \\
\text { nanoparticles }\end{array}$ & $\begin{array}{l}\text { - Polyethylene glycol coating } \\
\text { - PEP-1 }\end{array}$ & C6 glioma-bearing mice & [97] \\
\hline Paclitaxel & $\begin{array}{l}\text { Polymeric } \\
\text { nanoparticles }\end{array}$ & $\begin{array}{l}\text { - Polyethylene glycol coating } \\
\text { - Glucose }^{\mathrm{b}}\end{array}$ & RG-2 glioma-bearing mice & {$[71]$} \\
\hline Paclitaxel & $\begin{array}{l}\text { Polymeric } \\
\text { nanoparticles }\end{array}$ & $\begin{array}{l}\text { - Polyethylene glycol coating } \\
\text { - APT peptide }\end{array}$ & $\begin{array}{l}\text { U87MG glioblastoma- } \\
\text { bearing mice }\end{array}$ & [98] \\
\hline Paclitaxel & $\begin{array}{l}\text { Polymeric } \\
\text { nanoparticles }\end{array}$ & $\begin{array}{l}\text { - Polyethylene glycol coating } \\
\text { - iNGR peptide }\end{array}$ & $\begin{array}{l}\text { U87MG glioblastoma- } \\
\text { bearing mice }\end{array}$ & [75] \\
\hline Paclitaxel & $\begin{array}{l}\text { Polymeric } \\
\text { nanoparticles }\end{array}$ & $\begin{array}{l}\text { - Polyethylene glycol coating } \\
\text { - RGD peptide }\end{array}$ & $\begin{array}{l}\text { U87MG glioblastoma- } \\
\text { bearing mice }\end{array}$ & {$[74]$} \\
\hline Paclitaxel & $\begin{array}{l}\text { Polymeric } \\
\text { nanoparticles }\end{array}$ & $\begin{array}{l}\text { - Polyethylene glycol coating } \\
\text { - Angiopep }\end{array}$ & $\begin{array}{l}\text { U87MG glioblastoma- } \\
\text { bearing mice }\end{array}$ & {$[70]$} \\
\hline Gemcitabine & $\begin{array}{l}\text { Polymeric } \\
\text { nanoparticles }\end{array}$ & - Polysorbate- 80 coating ${ }^{a}$ & C6 glioma-bearing rats & [83] \\
\hline Aclarubicin & $\begin{array}{l}\text { Polymeric } \\
\text { nanoparticles }\end{array}$ & $\begin{array}{l}\text { - Polyethylene glycol coating } \\
\text { - Cationic serum albumin }{ }^{c}\end{array}$ & C6 glioma-bearing rats & [99] \\
\hline Camptothecin & $\begin{array}{l}\text { Polymeric } \\
\text { nanoparticles }\end{array}$ & None & $\begin{array}{l}\text { GL261 glioma-bearing } \\
\text { mice }\end{array}$ & [84] \\
\hline Doxorubicin & $\begin{array}{l}\text { Polymeric } \\
\text { nanoparticles }\end{array}$ & - Polysorbate- 80 coating ${ }^{\mathrm{a}}$ & $\begin{array}{l}101-8 \text { glioblastoma- } \\
\text { bearing rats }\end{array}$ & [100] \\
\hline Doxorubicin & $\begin{array}{l}\text { Polymeric } \\
\text { nanoparticles }\end{array}$ & $\begin{array}{l}\text { - Polysorbate-80/Poloxamer-188/ } \\
\text { Poloxamer-908 coating }\end{array}$ & $\begin{array}{l}101-8 \text { glioblastoma- } \\
\text { bearing rats }\end{array}$ & [101] \\
\hline Doxorubicin & $\begin{array}{l}\text { Polymeric } \\
\text { nanoparticles }\end{array}$ & $\begin{array}{l}\text { - Polysorbate-80/Poloxamer-188 } \\
\text { coating }^{\mathrm{a}}\end{array}$ & $\begin{array}{l}101-8 \text { glioblastoma- } \\
\text { bearing rats }\end{array}$ & [102] \\
\hline Docetaxel & $\begin{array}{l}\text { Polymeric } \\
\text { nanoparticles }\end{array}$ & $\begin{array}{l}\text { - Polyethylene glycol coating } \\
\text { - TGN peptide } \\
\text { - AS1411 aptamer }\end{array}$ & C6 glioma-bearing mice & [78] \\
\hline Docetaxel & $\begin{array}{l}\text { Polymeric } \\
\text { nanoparticles }\end{array}$ & $\begin{array}{l}\text { - Polyethylene glycol coating } \\
\text { - IL-13 peptide }\end{array}$ & $\begin{array}{l}\text { U87MG glioblastoma- } \\
\text { bearing mice }\end{array}$ & [103] \\
\hline Porphyrin & $\begin{array}{l}\text { Polymeric } \\
\text { nanoparticles }\end{array}$ & $\begin{array}{l}\text { - Polyethylene glycol coating } \\
\text { - F3 peptide } \\
\text { - Photodynamic therapy }\end{array}$ & 9L gliosarcoma-bearing rats & [104] \\
\hline
\end{tabular}




\begin{tabular}{|c|c|c|c|c|}
\hline $\begin{array}{l}\text { Encapsulated } \\
\text { drug }\end{array}$ & System & Strategy & Model & References \\
\hline Ferrociphenol & Lipid nanocapsules & - Polyethylene glycol coatinga & \multicolumn{2}{|c|}{ 9L gliosarcoma-bearing rats [85] } \\
\hline Doxorubicin & Dendrimers & $\begin{array}{l}\text { - Polyethylene glycol coating } \\
\text { - RGD peptide }\end{array}$ & C6 glioma-bearing mice & {$[88]$} \\
\hline $\begin{array}{l}\text { RNA antiEGFR } \\
\text { (miR-7) }\end{array}$ & Dendrimers & - Folate ${ }^{b}$ & U251 glioma-bearing mice & {$[105]$} \\
\hline DNA (TRAIL) & Dendrimers & $\begin{array}{l}\text { - Polyethylene glycol coating } \\
\text { - Chlorotoxin }\end{array}$ & C6 glioma-bearing mice & {$[80]$} \\
\hline DNA (TRAIL) & Dendrimers & $\begin{array}{l}\text { - Polyethylene glycol coating } \\
\text { - Angiopep }\end{array}$ & C6 glioma-bearing mice & {$[69]$} \\
\hline DNA (TRAIL) & Dendrimers & $\begin{array}{l}\text { - Polyethylene glycol coating } \\
\text { - RGD peptide }\end{array}$ & $\begin{array}{l}\text { U87MG glioblastoma- } \\
\text { bearing mice }\end{array}$ & [67] \\
\hline Paclitaxel & Polymeric micelles & $\begin{array}{l}\text { - Polyethylene glycol coating } \\
\text { - CDX peptide (candoxin) }\end{array}$ & & \\
\hline Paclitaxel & Polymeric micelles & $\begin{array}{l}\text { - Polyethylene glycol coating } \\
\text { - RGD peptide } \\
\text { - Transferrin }\end{array}$ & $\begin{array}{l}\text { U87MG glioblastoma- } \\
\text { bearing mice }\end{array}$ & [106] \\
\hline Paclitaxel & Polymeric micelles & $\begin{array}{l}\text { - Polyethylene glycol coating } \\
\text { - KC2S peptide }\end{array}$ & $\begin{array}{l}\text { U87MG glioblastoma- } \\
\text { bearing mice }\end{array}$ & {$[68]$} \\
\hline Paclitaxel & Polymeric micelles & $\begin{array}{l}\text { - Polyethylene glycol coating } \\
\text { - RGD peptide }\end{array}$ & $\begin{array}{l}\text { U87MG glioblastoma- } \\
\text { bearing mice }\end{array}$ & {$[107]$} \\
\hline Paclitaxel & Polymeric micelles & $\begin{array}{l}\text { - Polyethylene glycol coating } \\
\text { - CDX peptide }\end{array}$ & $\begin{array}{l}\text { U87MG glioblastoma- } \\
\text { bearing mice }\end{array}$ & {$[108]$} \\
\hline $\begin{array}{l}\text { Doxurubicin + } \\
\text { Paclitaxel }\end{array}$ & Polymeric micelles & $\begin{array}{l}\text { - Polyethylene glycol coating } \\
\text { - RGD peptide }\end{array}$ & $\begin{array}{l}\text { U87MG glioblastoma- } \\
\text { bearing mice }\end{array}$ & [109] \\
\hline $\begin{array}{l}\mathrm{SN}-38 \\
\text { (camptothecin } \\
\text { derivative) }\end{array}$ & Polymeric micelles & - Polyethylene glycol coatinga & $\begin{array}{l}\text { U87MG glioblastoma- } \\
\text { bearing mice }\end{array}$ & {$[110,111]$} \\
\hline Paclitaxel & $\begin{array}{l}\text { Magnetic } \\
\text { nanoparticles }\end{array}$ & - Magnetic fields ${ }^{\mathrm{e}}$ & C6 glioma-bearing rats & [112] \\
\hline Doxorubicin & Gold nanoparticles & $\begin{array}{l}\text { - Polyethylene glycol coating } \\
\text { - TAT peptide }\end{array}$ & $\begin{array}{l}\text { U87MG glioblastoma- } \\
\text { bearing mice }\end{array}$ & {$[113]$} \\
\hline
\end{tabular}

Strategies: a ${ }^{\text {a }}$ passive targeting; ${ }^{\mathrm{b}}$ : carrier/receptor-mediated active targeting; ${ }^{\mathrm{c}}$ : adsorption-mediated active targeting; ${ }^{\mathrm{d}}$ :

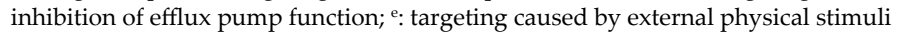

Table 3. Intravenously-administered nanomedicines already tested for efficacy in vivo against orthotopic rodent brain tumor models.

Most nanomedicines intended for preclinical evaluation following intravenous administration were designed to exploit passive and/or active targeting. Overall, stealth properties alone do 
not appear sufficient for enabling a nanoparticle-mediated transport into the brain, since in most cases of passively nonactively targeted nanomedicines survival benefits remained extremely modest [83-85].This could be due to the fact that PEG coating also reduces the tumor cell uptake of nanomedicines.

Additional active targeting using moieties that preferentially bind to receptors on the cerebral endothelial cells or overexpressed on brain tumor cells did indeed improve the therapeutic potential of nanomedicines due to preferential distribution to and within the brain tumor area: in all the studies with intravenously administered actively targeted nanomedicines, the median survival times were longer than their actively untargeted counterparts and noticeably longer than the untreated controls [75, 86-88].

However, most of these receptors are ubiquitously expressed to some degree. Hence, in order to prevent the occurrence of nonspecific side effects, dual-actively targeted have already been designed for achieving optimal targeting after systemic administration. In broad terms, the preclinical studies with these dual-targeted nanomedicines showed more extended survival times over their monotargeted counterparts $[65,73,78]$.

\section{Conclusions}

Despite the tremendous efforts thus far, malignant CNS tumors still represent an unmet medical need. Albeit the rapidly evolving knowledge about tumor biochemistry enables various new drug molecules to be designed as treatments, drug delivery in CNS tumors deserves explicit attention, as otherwise, novel therapies will continue to fail to expose the entire tumor and the infiltrate cells that are not located in the tumor bed to such therapeutics at pharmacologically meaningful quantities. In this regard, nanomedicine poses an appealing platform for efficient drug delivery to the CNS, since it may be targeted to improve the availability of the drugs in their site of action, which could be translated into lower drug doses and fewer side effects.

The BBTB restricts the permeation of most anticancer agents into the CNS, especially in areas where the BBTB more closely resembles the BBB. Therefore, one major challenge in the field of systemic chemotherapy is the development of nanomedicines that can effectively overcome the BBTB and allow specific targeting of brain cancer cells. Overall, the features of nanomedicines dictate their biological fate: size and surface charge, the surface hydration and/or the presence of targeting ligands on the surface. Concerning brain endothelium permeation, an ideal systemic nanomedicine for CNS drug delivery should be around or smaller than $100 \mathrm{~nm}$; be provided with a hydrophilic coating to avoid removal by the RES, extend its plasma halflife and indirectly increase the likelihood of crossing the brain endothelium; have targeting moieties to selectively enhance the distribution across the BBTB to the CNS and even be able to inhibit the drug efflux transporters at the BBTB. 


\begin{tabular}{|c|c|c|c|c|c|c|}
\hline $\begin{array}{l}\text { ClinicalTrials.gov } \\
\text { identifier }\end{array}$ & Condition & Treatment & Nanomedicine & $\begin{array}{l}\text { Route of } \\
\text { administration }\end{array}$ & $\begin{array}{l}\text { Targeting } \\
\text { approach }\end{array}$ & Phase \\
\hline NCT00003073" & CNS tumors & Cytarabine & $\begin{array}{l}\text { Liposome } \\
\left.\text { (DepoCyt }{ }^{\circledR}\right)\end{array}$ & Intrathecal & None & I \\
\hline NCT00029523c & $\begin{array}{l}\text { Neoplastic } \\
\text { meningitis }\end{array}$ & Cytarabine & $\begin{array}{l}\text { Liposome } \\
\left(\text { DepoCyt }{ }^{\circledR}\right)\end{array}$ & Intrathecal & None & Unspecified \\
\hline NCT00313599c & CNS tumors & $\begin{array}{l}\text { Paclitaxel } \\
\text { (+ oral lapatinib) }\end{array}$ & $\begin{array}{l}\text { Albumin } \\
\text { nanoparticles } \\
\text { (Abraxane }{ }^{\circledR} \text { ) }\end{array}$ & Intravenous & None & I \\
\hline NCT00019630' & $\begin{array}{l}\text { Brain tumors } \\
\text { (Children) }\end{array}$ & Doxorubicin & $\begin{array}{l}\text { Pegylated } \\
\text { liposome } \\
\text { (Lipodox®) }\end{array}$ & Intravenous & Passive & I \\
\hline NCT00465673 & Brain metastases & Doxorubicin & $\begin{array}{l}\text { Pegylated } \\
\text { liposome } \\
\left.\text { (Lipodox }{ }^{\circledR}\right)\end{array}$ & Intravenous & Passive & II \\
\hline NCT00734682 & $\begin{array}{l}\text { Glioblastoma } \\
\text { Gliosarcoma } \\
\text { Anaplastic } \\
\text { astrocytoma } \\
\text { Anaplastic } \\
\text { oligodendroglioma }\end{array}$ & Irinotecan & $\begin{array}{l}\text { Pegylated } \\
\text { liposome }\end{array}$ & Intravenous & Passive & I \\
\hline NCT00854867 ${ }^{\mathrm{c}}$ & $\begin{array}{l}\text { Neoplastic } \\
\text { meningitis }\end{array}$ & $\begin{array}{l}\text { Cytarabine (+ } \\
\text { concomitant/ } \\
\text { sequential } \\
\text { radiotherapy) }\end{array}$ & $\begin{array}{l}\text { Liposome } \\
\left.\text { (DepoCyt }{ }^{\circledR}\right)\end{array}$ & Intrathecal & None & I \\
\hline NCT00944801 $^{\mathrm{c}}$ & Glioblastoma & $\begin{array}{l}\text { Doxorubicin }(+ \\
\text { temozolomide }+ \\
\text { radiotherapy) }\end{array}$ & $\begin{array}{l}\text { Pegylated } \\
\text { liposome } \\
\left(\text { Caelix }{ }^{\circledR}\right)\end{array}$ & Intravenous & Passive & $\mathrm{I} / \mathrm{II}$ \\
\hline NCT00964743 ${ }^{\mathrm{t}}$ & $\begin{array}{l}\text { Neoplastic } \\
\text { meningitis }\end{array}$ & $\begin{array}{l}\text { Cytarabine } \\
(+ \text { oral } \\
\text { sorafenib })\end{array}$ & $\begin{array}{l}\text { Liposome } \\
\left(\text { DepoCyt }{ }^{\circledR}\right)\end{array}$ & $\begin{array}{l}\text { Intrathecal } \\
\text { (Ommaya } \\
\text { reservoir) }\end{array}$ & None & Unspecified \\
\hline NCT00992602 ${ }^{c}$ & $\begin{array}{l}\text { Leptomeningeal } \\
\text { metastases }\end{array}$ & $\begin{array}{l}\text { Cytarabine } \\
(+ \text { intravenous } \\
\text { methotrexate })\end{array}$ & $\begin{array}{l}\text { Liposome } \\
\left(\text { DepoCyt }{ }^{\circledR}\right)\end{array}$ & Intrathecal & None & II \\
\hline NCT01044966 ${ }^{t}$ & $\begin{array}{l}\text { Glioblastoma } \\
\text { multiforme } \\
\text { Glioma } \\
\text { Astrocytoma } \\
\text { Brain tumor }\end{array}$ & $\begin{array}{l}\text { Cytarabine } \\
(+ \text { oral } \\
\text { temozolomide })\end{array}$ & $\begin{array}{l}\text { Liposome } \\
\left(\text { DepoCyt }{ }^{\circledR}\right)\end{array}$ & Intrathecal & None & $\mathrm{I} / \mathrm{II}$ \\
\hline NCT01222780 & $\begin{array}{l}\text { Brain tumors } \\
\text { (Children) }\end{array}$ & Vincristine & $\begin{array}{l}\text { Liposome } \\
(\text { Marqibo®) }\end{array}$ & Intravenous & None & $\mathrm{I} / \mathrm{II}$ \\
\hline NCT01386580' & $\begin{array}{l}\text { Recurrent } \\
\text { malignant glioma } \\
\text { Brain metastases }\end{array}$ & Doxorubicin & $\begin{array}{l}\text { Glutathione } \\
\text { pegylated } \\
\text { liposome }\end{array}$ & Intravenous & $\begin{array}{l}\text { Passive } \\
+ \\
\text { Active }\end{array}$ & $\mathrm{I} / \mathrm{II}$ \\
\hline
\end{tabular}




\begin{tabular}{|c|c|c|c|c|c|c|}
\hline $\begin{array}{l}\text { ClinicalTrials.gov } \\
\text { identifier }\end{array}$ & Condition & Treatment & Nanomedicine & $\begin{array}{l}\text { Route of } \\
\text { administration }\end{array}$ & $\begin{array}{l}\text { Targeting } \\
\text { approach }\end{array}$ & Phase \\
\hline NCT01563614 ${ }^{\mathrm{t}}$ & $\begin{array}{l}\text { Leptomeningeal } \\
\text { metastases }\end{array}$ & $\begin{array}{l}\text { Cytarabine } \\
(+ \text { oral } \\
\text { lomustine + } \\
\text { radiotherapy) }\end{array}$ & $\begin{array}{l}\text { Liposome } \\
\left.\text { (DepoCyt }{ }^{\circledR}\right)\end{array}$ & Intrathecal & None & I \\
\hline NCT01818713 ${ }^{\mathrm{u}}$ & $\begin{array}{l}\text { Leptomeningeal } \\
\text { metastases }\end{array}$ & Doxorubicin & $\begin{array}{l}\text { Glutathione } \\
\text { pegylated } \\
\text { liposome }\end{array}$ & Intravenous & $\begin{array}{l}\text { Passive } \\
+ \\
\text { Active }\end{array}$ & II \\
\hline NCT02022644 ${ }^{\mathrm{r}}$ & High-grade glioma & Irinotecan & $\begin{array}{l}\text { Pegylated } \\
\text { liposome }\end{array}$ & CED & Passive & I \\
\hline NCT02340156r & Glioblastoma & $\begin{array}{l}\text { Normal human } \\
\text { wild type p53 } \\
\text { DNA sequence } \\
\text { (+ oral } \\
\text { temozolomide) }\end{array}$ & $\begin{array}{l}\text { Anti-transferrin } \\
\text { receptor single- } \\
\text { chain antibody } \\
\text { cationic } \\
\text { liposome }\end{array}$ & Intravenous & Active & II \\
\hline
\end{tabular}

Identifier of the current state of the clinical trial: ${ }^{\text {u}: ~ u n k n o w n ; ~}{ }^{\text {: }}$ completed; ${ }^{\text {t: }}$ terminated; ${ }^{\text {r: }}$ recruiting.

Table 4. Nanomedicines that have already reached the clinical trials stage for the treatment of CNS tumors.

Alternatively, nanomedicines can be locally administered to bypass the BBTB. However, CED and intrathecal delivery remain invasive approaches that carry significant risks for patients. An optimal nanomedicine for CED should be below $100 \mathrm{~nm}$, neutral or negatively charged, conjugated to specific ligands that bind the tumor cell receptors and be infused in a slight viscous and hyperosmolar solution.

Overall, nanomedicines intended for brain delivery either for systemic or local delivery should ideally be biocompatible and biodegradable, have a controllable release profile to trigger drug release at the site of action, be able to be sterilized and have a feasible industrial production for clinical implementation.

On the basis of the promising results gathered from preclinical studies of nanomedicine-based therapy, some nanomedicines have already been approved for clinical trials in a variety of CNS tumors conditions to serve as the first steps in translation of nanotherapy to clinic (Table 4). Therefore, their outcome will steer further research directions and when successful, will provide handles for further improvements. Unfortunately, the results of the already completed clinical trials are not yet available on clinicaltrials.gov.

It is worth underlining the fact that current clinical trials using nanomedicines for brain tumors are conducted on patients who have failed conventional therapy and have very poor prognosis (mostly recurrent high-grade glioma or brain metastases). However, expanding the application of nanomedicine to less aggressive forms of brain cancer is challenging, as long as the longterm side effects due to the interactions of colloids with biological structures are not yet known and, consequently, the regulatory agencies have not yet developed comprehensive regulatory guidelines for nanomedicines. 
In view of the approved clinical trials, some general conclusions can be drawn. On the one hand, whereas several liposomal formulations are already under clinical trials, the rest of types of nanomedicines are lagging behind. The investigation of nanomedicines for CNS delivery has focused largely on liposomal preparations mostly due to the fact that their potential as drug carriers was already acknowledged back in the 1970s, much earlier than any other alternative nanocarrier.

On the other hand, most liposomes that reached clinical trials for the treatment of brain tumors are passively targeted, avoiding the ligand-receptor interaction. Despite the promising preclinical results, translation of active targeting to clinical trials poses some challenges, since most targeted receptors are not exclusively present at the BBTB and/or brain tumor cells, which may give raise to side effects. Additionally, nanomedicines conjugated with physiological ligands can develop competitive phenomena with endogenous ligands and dysregulate their homeostasis, whereas nanomedicines that incorporate monoclonal antibodies must be able to interact with human receptors to not cause immunogenic reactions; hence, presumably different from those antibodies assayed in rodent preclinical models. Nonetheless, two actively targeted liposomes have recently made their way to clinical trials to cross the BBB after intravenous injection for achieving higher and efficacious brain drug levels: 2B3-101 is a PEGylated liposomal doxorubicin formulation conjugated with glutathione and SGT-53 is a cationic liposome conjugated with an antitransferrin receptor single-chain antibody and encapsulating a normal human wild-type p53 DNA sequence to restore the wild-type p53 function and downmodulate MGMT activity in order to increase the sensitivity of tumor cells to alkylating agents.

Concerning the different routes of administration, intravenous among the systemic routes and CED and intrathecal delivery among the local routes have even made its way into clinical trials for nanoparticle administration.

In conclusion, clinical implementation of nanomedicines for patients with brain tumors is still in its infancy. However, further clinical studies of brain-targeted nanomedicines are warranted in the future, with increasing incidences of CNS cancers, many of whom being terrible rapidly progressing and so far untreatable tumors. Hence, the accumulation of data about the CNS physiology and about relevant receptors, the widening therapeutic armamentarium of drugs potentially useful in CNS chemotherapy, the alternative routes for administration and the estimation of the brain permeability with in vitro BBB models to early triage the potential of nanomedicines for optimum therapy of brain tumors envisage nanomedicines as a forthcoming routine approach [114].

\section{Acknowledgements}

This work was partially funded by the Research Group GR35/10 Santander-UCM, Group: Parenteral Administration of Drugs. Juan Aparicio-Blanco thanks the Spanish Ministry of Education for the Contract within the Professor Training Program FPU (Ref. FPU13/02325). 


\section{Author details}

Juan Aparicio-Blanco and Ana-Isabel Torres-Suárez*

*Address all correspondence to: galaaaa@ucm.es

Department of Pharmaceutical Technology, Faculty of Pharmacy, Complutense University, Madrid, Spain

\section{References}

[1] Louis DN, Ohgaki H, Wiestler OD, Cavenee WK, Burger PC, Jouvet A, Scheithauer BW, Kleihues P. The 2007 WHO classification of tumours of the central nervous system. Acta Neuropathol. 2007;114:97-109.

[2] Schwartzbaum JA, Fisher JL, Aldape KD, Wrensch M. Epidemiology and molecular pathology of glioma. Nat Clin Pract Neurol. 2006;2:494-503.

[3] Wen PY, Kesari S. Malignant gliomas in adults. N Engl J Med. 2008;359:492-507.

[4] Alifieris C, Trafalis DT. Glioblastoma multiforme: pathogenesis and treatment. Pharmacol Ther. 2015;152:63-82.

[5] Stupp R, Mason WP, van den Bent MJ, Weller M, Fisher B, Taphoorn MJB, Belanger K, Brandes AA, Marosi C, Bogdahn U, Curschmann J, Janzer RC, Ludwin SK, Gorlia T, Allgeier A, Lacombe D, Cairncross JG, Eisenhauer E, Mirimanoff RO, Van Den Weyngaert D, Kaendler S, Krauseneck P, Vinolas N, Villa S, Wurm RE, Maillot MHB, Spagnolli F, Kantor G, Malhaire JP, Renard L, De Witte O, Scandolaro L, Vecht CJ, Maingon P, Lutterbach J, Kobierska A, Bolla M, Souchon R, Mitine C, Tzuk-Shina T, Kuten A, Haferkamp G, de Greve J, Priou F, Menten J, Rutten I, Clavere P, Malmstrom A, Jancar B, Newlands E, Pigott K, Twijnstra A, Chinot O, Reni M, Boiardi A, Fabbro M, Campone M, Bozzino J, Frenay M, Gijtenbeek J, Brandes AA, Delattre JY, Bogdahn U, De Paula U, van den Bent MJ, Hanzen C, Pavanato G, Schraub S, Pfeffer R, Soffietti R, Weller M, Kortmann RD, Taphoorn M, Torrecilla JL, Marosi C, Grisold W, Huget P, Forsyth P, Fulton D, Kirby S, Wong R, Fenton D, Fisher B, Cairncross G, Whitlock P, Belanger K, Burdette-Radoux S, Gertler S, Saunders S, Laing K, Siddiqui J, Martin LA, Gulavita S, Perry J, Mason W, Thiessen B, Pai H, Alam ZY, Eisenstat D, Mingrone W, Hofer S, Pesce G, Curschmann J, Dietrich PY, Stupp R, Mirimanoff RO, Thum P, Baumert B, Ryan G, European Org Res Treatment Canc B. Radiotherapy plus concomitant and adjuvant temozolomide for glioblastoma. N Engl J Med. 2005;352:987-996.

[6] Messaoudi K, Clavreul A, Lagarce F. Toward an effective strategy in glioblastoma treatment. Part I: resistance mechanisms and strategies to overcome resistance of glioblastoma to temozolomide. Drug Discov Today. 2015;20:899-905. 
[7] Esteller M, Garcia-Foncillas J, Andion E, Goodman SN, Hidalgo OF, Vanaclocha V, Baylin SB, Herman JG. Inactivation of the DNA-repair gene MGMT and the clinical response of gliomas to alkylating agents. N Engl J Med. 2000;343:1350-1354.

[8] Hegi ME, Diserens A, Gorlia T, Hamou M, de Tribolet N, Weller M, Kros JM, Hainfellner JA, Mason W, Mariani L, Bromberg JEC, Hau P, Mirimanoff RO, Cairncross JG, Janzer RC, Stupp R. MGMT gene silencing and benefit from temozolomide in glioblastoma. N Engl J Med. 2005;352:997-1003.

[9] de Faria GP, de Oliveira JA, de Oliveira JGP, Romano SD, Neto VM, Maia RC. Differences in the expression pattern of P-glycoprotein and MRP1 in low-grade and highgrade gliomas. Cancer Invest. 2008;26:883-889.

[10] Holohan C, Van Schaeybroeck S, Longley DB, Johnston PG. Cancer drug resistance: an evolving paradigm. Nat Rev Cancer. 2013;13:714-726.

[11] VanTellingen O, Yetkin-Arik B, De Gooijer MC, Wesseling P, Wurdinger T, De Vries HE. Overcoming the blood-brain tumor barrier for effective glioblastoma treatment. Drug Resist Update. 2015;19:1-12.

[12] Schinkel AH. P-glycoprotein, a gatekeeper in the blood-brain barrier. Adv Drug Deliv Rev. 1999;36:179-194.

[13] Westphal M, Hilt DC, Bortey E, Delavault P, Olivares R, Warnke PC, Whittle IR, Jaaskelainen J, Ram Z. A phase 3 trial of local chemotherapy with biodegradable carmustine (BCNU) wafers (Gliadel wafers) in patients with primary malignant glioma. Neuro-Oncology. 2003;5:79-88.

[14] Davis ME, Chen Z, Shin DM. Nanoparticle therapeutics: an emerging treatment modality for cancer. Nat Rev Drug Discov. 2008;7:771-782.

[15] Cheng Y, Morshed RA, Auffinger B, Tobias AL, Lesniak MS. Multifunctional nanoparticles for brain tumor imaging and therapy. Adv Drug Deliv Rev. 2014;66:42-57.

[16] Karim R, Palazzo C, Evrard B, Piel G. Nanocarriers for the treatment of glioblastoma multiforme: current state-of-the-art. J Control Release. 2016;227:23-37.

[17] Cupaioli FA, Zucca FA, Boraschi D, Zecca L. Engineered nanoparticles. How brain friendly is this new guest? Prog Neurobiol. 2014;119:20-38.

[18] Lai F, Fadda AM, Sinico C. Liposomes for brain delivery. Expert Opin Drug Deliv. 2013;10:1003-1022.

[19] Gastaldi L, Battaglia L, Peira E, Chirio D, Muntoni E, Solazzi I, Gallarate M, Dosio F. Solid lipid nanoparticles as vehicles of drugs to the brain: current state of the art. Eur J PharmBiopharm. 2014;87:433-444.

[20] Aparicio-Blanco J, Torres-Suarez AI. Glioblastoma multiforme and lipid nanocapsules: a review. J Biomed Nanotechnol. 2015;11:1283-1311. 
[21] Patel T, Zhou JB, Piepmeier JM, Saltzman WM. Polymeric nanoparticles for drug delivery to the central nervous system. Adv Drug Deliv Rev. 2012;64:701-705.

[22] Costantino L, Boraschi D. Is there a clinical future for polymeric nanoparticles as braintargeting drug delivery agents? Drug Discov Today. 2012;17:367-378.

[23] Mishra V, Kesharwani P. Dendrimer technologies for brain tumor. Drug Discov Today. 2016;21:766-778.

[24] Singh D, McMillan JM, Kabanov AV, Sokolsky-Papkov M, Gendelman HE. Bench-tobedside translation of magnetic nanoparticles. Nanomedicine. 2014;9:501-516.

[25] Jabr-Milane LS, van Vlerken LE, Yadav S, Amiji MM. Multi-functional nanocarriers to overcome tumor drug resistance. Cancer Treat Rev. 2008;34:592-602.

[26] Allard E, Passirani C, Benoit JP. Convection-enhanced delivery of nanocarriers for the treatment of brain tumors. Biomaterials. 2009;30:2302-2318.

[27] MacKay JA, Deen DF, Szoka FC. Distribution in brain of liposomes after convection enhanced delivery; modulation by particle charge, particle diameter, and presence of steric coating. Brain Res. 2005;1035:139-153.

[28] Serwer LP, James CD. Challenges in drug delivery to tumors of the central nervous system: an overview of pharmacological and surgical considerations. Adv Drug Deliv Rev. 2012;64:590-597.

[29] Mistry A, Stolnik S, Illum L. Nanoparticles for direct nose-to-brain delivery of drugs. Int J Pharm. 2009;379:146-157.

[30] Noble CO, Krauze MT, Drummond DC, Yamashita Y, Saito R, Berger MS, Kirpotin DB, Bankiewicz KS, Park JW. Novel nanoliposomal CPT-11 infused by convection-enhanced delivery in intracranial tumors: pharmacology and efficacy. Cancer Res. 2006;66:2801-2806.

[31] Saito R, Krauze MT, Noble CO, Drummond DC, Kirpotin DB, Berger MS, Park JW, Bankiewicz KS. Convection-enhanced delivery of Ls-TPT enables an effective, continuous, low-dose chemotherapy against malignant glioma xenograft model. NeuroOncology. 2006;8:205-214.

[32] Chen PY, Ozawa T, Drummond DC, Kalra A, Fitzgerald JB, Kirpotin DB, Wei KC, Butowski N, Prados MD, Berger MS, Forsayeth JR, Bankiewicz K, James CD. Comparing routes of delivery for nanoliposomal irinotecan shows superior anti-tumor activity of local administration in treating intracranial glioblastoma xenografts. NeuroOncology. 2013;15:189-197.

[33] Yamashita Y, T Krauze M, Kawaguchi T, Noble CO, Drummond DC, Park JW, Bankiewicz KS. Convection-enhanced delivery of a topoisomerase I inhibitor (nanoliposomaltopotecan) and a topoisomerase II inhibitor (pegylated liposomal doxorubicin) in intracranial brain tumor xenografts. Neuro-Oncology. 2007;9:20-28. 
[34] Krauze MT, Noble CO, Kawaguchi T, Drummond D, Kirpotin DB, Yamashita Y, Kullberg E, Forsayeth J, Park JW, Bankiewicz KS. Convection-enhanced delivery of nanoliposomal CPT-11 (irinotecan) and PEGylated liposomal doxorubicin (Doxil) in rodent intracranial brain tumor xenografts. Neuro-Oncology. 2007;9:393-403.

[35] Stephen ZR, Kievit FM, Veiseh O, Chiarelli PA, Fang C, Wang K, Hatzinger SJ, Ellenbogen RG, Silber JR, Zhang MQ. Redox-responsive magnetic nanoparticle for targeted convection-enhanced delivery of o-6-benzylguanine to brain tumors. ACS Nano. 2014;8:10383-10395.

[36] Grahn AY, Bankiewicz KS, Dugich-Djordjevic M, Bringas JR, Hadaczek P, Johnson GA, Eastman S, Luz M. Non-PEGylated liposomes for convection-enhanced delivery of topotecan and gadodiamide in malignant glioma: initial experience. J Neuro-Oncol. 2009;95:185-197.

[37] Huynh NT, Passirani C, Allard-Vannier E, Lemaire L, Roux J, Garcion E, Vessieres A, Benoit JP. Administration-dependent efficacy of ferrociphenol lipid nanocapsules for the treatment of intracranial 9L rat gliosarcoma. Int J Pharm. 2012;423:55-62.

[38] Laine AL, Huynh NT, Clavreul A, Balzeau J, Bejaud J, Vessieres A, Benoit JP, Eyer J, Passirani C. Brain tumour targeting strategies via coated ferrociphenol lipid nanocapsules. Eur J Pharm Biopharm. 2012;81:690-693.

[39] Hadjipanayis CG, Machaidze R, Kaluzova M, Wang LY, Schuette AJ, Chen HW, Wu XY, Mao H. EGFRvIII antibody-conjugated Iron Oxide nanoparticles for magnetic resonance imaging-guided convection-enhanced delivery and targeted therapy of glioblastoma. Cancer Res. 2010;70:6303-6312.

[40] Kaluzova M, Bouras A, Machaidze R, Hadjipanayis CG. Targeted therapy of glioblastoma stem-like cells and tumor non-stem cells using cetuximab-conjugated iron-oxide nanoparticles. Oncotarget. 2015;6:8788-9806.

[41] Inoue T, Yamashita Y, Nishihara M, Sugiyama S, Sonoda Y, Kumabe T, Yokoyama M, Tominaga T. Therapeutic efficacy of a polymeric micellar doxorubicin infused by convection-enhanced delivery against intracranial 9L brain tumor models. NeuroOncology. 2009;11:151-157.

[42] Wu G, Barth RF, Yang WL, Kawabata S, Zhang LW, Green-Church K. Targeted delivery of methotrexate to epidermal growth factor receptor-positive brain tumors by means of cetuximab (IMC-C225) dendrimer bioconjugates. Mol Cancer Ther. 2006;5:52-59.

[43] Barth RF, Wu G, Meisen WH, Nakkula RJ, Yang W, Huo T, Kellough DA, Kaumaya P, Turro C, Agius LM, Kaur B. Design, synthesis, and evaluation of cisplatin-containing EGFR targeting bioconjugates as potential therapeutic agents for brain tumors. Onco Targets Ther. 2016;9:2769-2781.

[44] Taki H, Kanazawa T, Akiyama F, Takashima Y, Okada H. Intranasal delivery of camptothecin-loaded tat-modified nanomicells for treatment of intracranial brain tumors. Pharmaceuticals (Basel, Switzerland). 2012;5:1092-1102. 
[45] Kanazawa T, Morisaki K, Suzuki S, Takashima Y. Prolongation of life in rats with malignant glioma by intranasal siRNA/drug codelivery to the brain with cell-penetrating peptide-modified micelles. Mol Pharm. 2014;11:1471-1478.

[46] Sawyer AJ, Saucier-Sawyer JK, Booth CJ, Liu J, Patel T, Piepmeier JM, Saltzman WM. Convection-enhanced delivery of camptothecin-loaded polymer nanoparticles for treatment of intracranial tumors. Drug Deliv Transl Res. 2011;1:34-42.

[47] Bernal GM, LaRiviere MJ, Mansour N, Pytel P, Cahill KE, Voce DJ, Kang SJ, Spretz R, Welp U, Noriega SE, Nunez L, Larsen G, Weichselbaum RR, Yamini B. Convectionenhanced delivery and in vivo imaging of polymeric nanoparticles for the treatment of malignant glioma. Nanomed-Nanotechnol Biol Med. 2014;10:149-157.

[48] Mangraviti A, Tzeng SY, Kozielski KL, Wang Y, Jin YK, Gullotti D, Pedone M, Buaron N, Liu A, Wilson DR, Hansen SK, Rodriguez FJ, Gao GD, DiMeco F, Brem H, Olivi A, Tyler B, Green JJ. Polymeric nanoparticles for nonviral gene therapy extend brain tumor survival in vivo. ACS Nano. 2015;9:1236-1249.

[49] Vinchon-Petit S, Jarnet D, Paillard A, Benoit JP, Garcion E, Menei P. In vivo evaluation of intracellular drug-nanocarriers infused into intracranial tumours by convectionenhanced delivery: distribution and radiosensitisation efficacy. J Neuro-Oncol. 2010;97:195-205.

[50] Allard E, Huynh NT, Vessieres A, Pigeon P, Jaouen G, Benoit JP, Passirani C. Dose effect activity of ferrocifen-loaded lipid nanocapsules on a 9L-glioma model. Int J Pharm. 2009;379:317-323.

[51] Allard E, Jarnet D, Vessieres A, Vinchon-Petit S, Jaouen G, Benoit JP, Passirani C. Local delivery of Ferrociphenol Lipid nanocapsules followed by external Radiotherapy as a synergistic treatment against intracranial 9L glioma xenograft. Pharm Res. 2010;27:5664.

[52] Yokosawa M, Sonoda Y, Sugiyama S, Saito R, Yamashita Y, Nishihara M, Satoh T, Kumabe T, Yokoyama M, Tominaga T. Convection-enhanced delivery of a synthetic retinoid Am80, loaded into polymeric micelles, prolongs the survival of rats bearing intracranial glioblastoma xenografts. Tohoku J Exp Med. 2010;221:257-264.

[53] Peluffo H, Unzueta U, Negro-Demontel ML, Xu ZK, Vaquez E, Ferrer-Miralles N, Villaverde A. BBB-targeting, protein-based nanomedicines for drug and nucleic acid delivery to the CNS. Biotechnol Adv. 2015;33:277-287.

[54] Maeda H, Wu J, Sawa T, Matsumura Y, Hori K. Tumor vascular permeability and the EPR effect in macromolecular therapeutics: a review. J Control Release. 2000;65:271284.

[55] Beduneau A, Saulnier P, Benoit JP. Active targeting of brain tumors using nanocarriers. Biomaterials. 2007;28:4947-4967.

[56] Alyautdin R, Khalin I, Nafeeza MI, Haron MH, Kuznetsov D. Nanoscale drug delivery systems and the blood-brain barrier. Int J Nanomed. 2014;9:795-811. 
[57] Dobrovolskaia MA, McNeil SE. Immunological properties of engineered nanomaterials. Nat Nanotechnol. 2007;2:469-478.

[58] Gref R, Luck M, Quellec P, Marchand M, Dellacherie E, Harnisch S, Blunk T, Muller $\mathrm{RH}$. 'Stealth' corona-core nanoparticles surface modified by polyethylene glycol (PEG): influences of the corona (PEG chain length and surface density) and of the core composition on phagocytic uptake and plasma protein adsorption. Colloid Surf BBiointerfaces. 2000;18:301-313.

[59] Rapoport SI, Robinson PJ. Tight-junctional modification as the basis of osmotic opening of the blood-brain barrier. Ann NY Acad Sci. 1986;481:250-267.

[60] Nakano S, Matsukado K, Black KL. Increased brain tumor microvessel permeability after intracarotid bradykinin infusion is mediated by nitric oxide. Cancer Res. 1996;56:4027-4031.

[61] Hynynen K, McDannold N, Vykhodtseva N, Raymond S, Weissleder R, Jolesz FA, Sheikov N. Focal disruption of the blood-brain barrier due to $260-\mathrm{kHz}$ ultrasound bursts: a method for molecular imaging and targeted drug delivery. J Neurosurg. 2006;105:445-454.

[62] Oller-Salvia B, Sanchez-Navarro M, Giralt E, Teixido M. Blood-brain barrier shuttle peptides: an emerging paradigm for brain delivery. Chemical Society Reviews. 2016;45:4690-4707.

[63] Zhang Y, Zhang YF, Bryant J, Charles A, Boado RJ, Pardridge WM. Intravenous RNA interference gene therapy targeting the human epidermal growth factor receptor prolongs survival in intracranial brain cancer. Clin Cancer Res. 2004;10:3667-3677.

[64] Wei L, Guo X-Y, Yang T, Yu M-Z, Chen D-W, Wang J-C. Brain tumor-targeted therapy by systemic delivery of siRNA with Transferrin receptor-mediated core-shell nanoparticles. Int J Pharm. 2016;510:394-405.

[65] Yue PJ, He L, Qiu SW, Li Y, Liao YJ, Li XP, Xie D, Peng Y. OX26/CTX-conjugated PEGylated liposome as a dual-targeting gene delivery system for brain glioma. Mol Cancer. 2014;13:13.

[66] Wei XL, Zhan CY, Shen Q, Fu W, Xie C, Gao J, Peng CM, Zheng P, Lu WY. A D-Peptide ligand of Nicotine Acetylcholine Receptors for brain-targeted drug delivery. Angew Chem-Int Edit. 2015;54:3023-3027.

[67] Zhan CY, Wei XL, Qian J, Feng LL, Zhu JH, Lu WY. Co-delivery of TRAIL gene enhances the anti-glioblastoma effect of paclitaxel in vitro and in vivo. J Control Release. 2012;160:630-636.

[68] Zhan CY, Yan ZQ, Xie C, Lu WY. Loop 2 of Ophiophagushannah Toxin b binds with Neuronal Nicotinic Acetylcholine receptors and enhances intracranial drug delivery. Mol Pharm. 2010;7:1940-1947. 
[69] Huang SX, Li JF, Han L, Liu SH, Ma HJ, Huang RQ, Jiang C. Dual targeting effect of Angiopep-2-modified, DNA-loaded nanoparticles for glioma. Biomaterials. 2011;32: 6832-6838.

[70] Xin HL, Sha XY, Jiang XY, Zhang W, Chen LC, Fang XL. Anti-glioblastoma efficacy and safety of paclitaxel-loading Angiopep-conjugated dual targeting PEG-PCL nanoparticles. Biomaterials. 2012;33:8167-8176.

[71] Jiang XY, Xin HL, Ren QY, Gu JJ, Zhu LJ, Du FY, Feng CL, Xie YK, Sha XY, Fang XL. Nanoparticles of 2-deoxy-D-glucose functionalized poly(ethylene glycol)-co-poly(trimethylene carbonate) for dual-targeted drug delivery in glioma treatment. Biomaterials. 2014;35:518-529.

[72] Ying X, Wen H, Lu WL, Du J, Guo J, Tian W, Men Y, Zhang Y, Li RJ, Yang TY, Shang DW, Lou JN, Zhang LR, Zhang Q. Dual-targeting daunorubicin liposomes improve the therapeutic efficacy of brain glioma in animals. J Control Release. 2010;141:183-192.

[73] Shi KR, Long Y, Xu CQ, Wang Y, Qiu Y, Yu QW, Liu YY, Zhang QY, Gao HL, Zhang ZR, $\mathrm{He} \mathrm{Q}$. Liposomes combined an integrin alpha(v)beta(3)-specific vector with $\mathrm{pH}$ responsible cell-penetrating property for highly effective antiglioma therapy through the blood-brain barrier. ACS Appl Mater Interfaces. 2015;7:21442-1454.

[74] Jiang XY, Sha XY, Xin HL, Xu XM, Gu JJ, Xia WY, Chen S, Xie YK, Chen LC, Chen YZ, Fang XL. Integrin-facilitated transcytosis for enhanced penetration of advanced gliomas by poly(trimethylene carbonate)-based nanoparticles encapsulating paclitaxel. Biomaterials. 2013;34:2969-2979.

[75] Kang T, Gao XL, Hu QY, Jiang D, Feng XY, Zhang X, Song QX, Yao L, Huang M, Jiang $X G$, Pang ZQ, Chen HZ, Chen J. iNGR-modified PEG-PLGA nanoparticles that recognize tumor vasculature and penetrate gliomas. Biomaterials. 2014;35:4319-4332.

[76] Hu QY, Gu GZ, Liu ZY, Jiang MY, Kang T, Miao DY, Tu YF, Pang ZQ, Song QX, Yao L, Xia HM, Chen HZ, Jiang XG, Gao XL, Chen J. F3 peptide-functionalized PEG-PLA nanoparticles co-administrated with tLyp-1 peptide for anti-glioma drug delivery. Biomaterials. 2013;34:1135-1145.

[77] Guo JW, Gao XL, Su LN, Xia HM, Gu GZ, Pang ZQ, Jiang XG, Yao L, Chen J, Chen HZ. Aptamer-functionalized PEG-PLGA nanoparticles for enhanced anti-glioma drug delivery. Biomaterials. 2011;32:8010-8020.

[78] Gao HL, Qian J, Cao SJ, Yang Z, Pang ZQ, Pan SQ, Fan L, Xi ZJ, Jiang XG, Zhang QZ. Precise glioma targeting of and penetration by aptamer and peptide dual-functioned nanoparticles. Biomaterials. 2012;33:5115-5123.

[79] Yang FY, Wong TT, Teng MC, Liu RS, Lu M, Liang HF, Wei MC. Focused ultrasound and interleukin-4 receptor-targeted liposomal doxorubicin for enhanced targeted drug delivery and antitumor effect in glioblastoma multiforme. J Control Release. 2012;160:652-658. 
[80] Huang RQ, Ke WL, Han LA, Li JF, Liu SH, Jiang C. Targeted delivery of chlorotoxinmodified DNA-loaded nanoparticles to glioma via intravenous administration. Biomaterials. 2011;32:2399-2406.

[81] Liu Y, Lu WY. Recent advances in brain tumor-targeted nano-drug delivery systems. Expert Opin Drug Deliv. 2012;9:671-686.

[82] Liu HL, Hua MY, Yang HW, Huang CY, Chu PC, Wu JS, Tseng IC, Wang JJ, Yen TC, Chen PY, Wei KC. Magnetic resonance monitoring of focused ultrasound/magnetic nanoparticle targeting delivery of therapeutic agents to the brain. Proc Natl AcadSci U S A. 2010;107:15205-15210.

[83] Wang CX, Huang LS, Hou LB, Jiang L, Yan ZT, Wang YL, Chen ZL. Antitumor effects of polysorbate- 80 coated gemcitabine polybutylcyanoacrylate nanoparticles in vitro and its pharmacodynamics in vivo on C6 glioma cells of a brain tumor model. Brain Res. 2009;1261:91-99.

[84] Householder KT, DiPerna DM, Chung EP, Wohlleb GM, Dhruv HD, Berens ME, Sirianni RW. Intravenous delivery of camptothecin-loaded PLGA nanoparticles for the treatment of intracranial glioma. Int J Pharm. 2015;479:374-380.

[85] Huynh NT, Morille M, Bejaud J, Legras P, Vessieres A, Jaouen G, Benoit JP, Passirani C. Treatment of 9L gliosarcoma in rats by Ferrociphenol-loaded lipid nanocapsules based on a passive targeting strategy via the EPR effect. Pharm Res. 2011;28:3189-3198.

[86] Gaillard PJ, Appeldoorn CCM, Dorland R, van Kregten J, Manca F, Vugts DJ, Windhorst B, van Dongen G, de Vries HE, Maussang D, Van Tellingen O. Pharmacokinetics, brain delivery, and efficacy in brain tumor-bearing mice of glutathione pegylated liposomal doxorubicin (2B3-101). PLoS One. 2014;9:10.

[87] Zhang B, Sun XY, Mei H, Wang Y, Liao ZW, Chen J, Zhang QZ, Hu Y, Pang ZQ, Jiang $X G$. LDLR-mediated peptide-22-conjugated nanoparticles for dual-targeting therapy of brain glioma. Biomaterials. 2013;34:9171-9182.

[88] Zhang LH, Zhu SJ, Qian LL, Pei YY, Qiu YM, Jiang YY. RGD-modified PEG-PAMAMDOX conjugates: In vitro and in vivo studies for glioma. Eur J Pharm Biopharm. 2011;79:232-240.

[89] Zhou R, Mazurchuk RV, Tamburlin JH, Harrold JM, Mager DE, Straubinger RM. Differential pharmacodynamic effects of paclitaxel formulations in an intracranial rat brain tumor model. J Pharmacol Exp Ther. 2010;332:479-488.

[90] Noble CO, Krauze MT, Drummond DC, Forsayeth J, Hayes ME, Beyer J, Hadaczek P, Berger MS, Kirpotin DB, Bankiewicz KS, Park JW. Pharmacokinetics, tumor accumulation and antitumor activity of nanoliposomal irinotecan following systemic treatment of intracranial tumors. Nanomedicine. 2014;9:2099-2108.

[91] Du J, Lu WL, Ying X, Liu Y, Du P, Tian W, Men Y, Guo J, Zhang Y, Li RJ, Zhou J, Lou JN, Wang JC, Zhang X, Zhang Q. Dual-targeting topotecan liposomes modified with tamoxifen and wheat germ agglutinin significantly improve drug transport across the 
blood-brain barrier and survival of brain tumor-bearing animals. Mol Pharm. 2009;6:905-917.

[92] Serwer LP, Noble CO, Michaud K, Drummond DC, Kirpotin DB, Ozawa T, Prados MD, Park JW, James CD. Investigation of intravenous delivery of nanoliposomaltopotecan for activity against orthotopic glioblastoma xenografts. Neuro-Oncology. 2011;13:12881295.

[93] Gao JQ, Lv Q, Li LM, Tang XJ, Li FZ, Hu YL, Han M. Glioma targeting and blood-brain barrier penetration by dual-targeting doxorubincin liposomes. Biomaterials. 2013;34:5628-5639.

[94] Chen HL, Qin Y, Zhang QY, Jiang W, Tang L, Liu J, He Q. Lactoferrin modified doxorubicin-loaded procationic liposomes for the treatment of gliomas. Eur J Pharm Sci. 2011;44:164-173.

[95] Gong W, Wang ZY, Liu N, Lin W, Wang XP, Xu D, Liu HY, Zeng CY, Xie XY, Mei XG, Lu WL. Improving efficiency of adriamycin crossing blood brain barrier by combination of thermosensitive liposomes and hyperthermia. Biol Pharm Bull. 2011;34:10581064 .

[96] Tian W, Ying X, Du J, Guo J, Men Y, Zhang Y, Li RJ, Yao HJ, Lou JN, Zhang LR, Lu WL. Enhanced efficacy of functionalized epirubicin liposomes in treating brain gliomabearing rats. Eur J Pharm Sci. 2010;41:232-243.

[97] Wang BY, Lv LY, Wang Z, Jiang Y, Lv W, Liu X, Wang ZY, Zhao Y, Xin HL, Xu QW. Improved anti-glioblastoma efficacy by IL-13R alpha 2 mediated copolymer nanoparticles loaded with paclitaxel. Sci Rep. 2015;5:13.

[98] Gu GZ, Hu QY, Feng XY, Gao XL, Jiang ML, Kang T, Jiang D, Song QX, Chen HZ, Chen J. PEG-PLA nanoparticles modified with APT(EDB) peptide for enhanced antiangiogenic and anti-glioma therapy. Biomaterials. 2014;35:8215-8226.

[99] Lu W, Wan J, Zhang Q, She ZJ, Jiang XG. Aclarubicin-loaded cationic albuminconjugated pegylated nanoparticle for glioma chemotherapy in rats. Int J Cancer. 2007;120:420-431.

[100] Steiniger SCJ, Kreuter J, Khalansky AS, Skidan IN, Bobruskin AI, Smirnova ZS, Severin SE, Uhl R, Kock M, Geiger KD, Gelperina SE. Chemotherapy of glioblastoma in rats using doxorubicin-loaded nanoparticles. Int J Cancer. 2004;109:759-767.

[101] Ambruosi A, Gelperina S, Khalansky A, Tanski S, Theisen A, Kreuter J. Influence of surfactants, polymer and doxorubicin loading on the anti-tumour effect of poly(butyl cyanoacrylate) nanoparticles in a rat glioma model. J Microencapsul. 2006;23:582-592.

[102] Gelperina S, Maksimenko O, Khalansky A, Vanchugova L, Shipulo E, Abbasova K, Berdiev R, Wohlfart S, Chepurnova N, Kreuter J. Drug delivery to the brain using surfactant-coated poly(lactide-co-glycolide) nanoparticles: influence of the formulation parameters. Eur J Pharm Biopharm. 2010;74:157-163. 
[103] Gao HL, Yang Z, Zhang S, Cao SJ, Shen S, Pang ZQ, Jiang XG. Ligand modified nanoparticles increases cell uptake, alters endocytosis and elevates glioma distribution and internalization. Sci Rep. 2013;3:8.

[104] Reddy GR, Bhojani MS, McConville P, Moody J, Moffat BA, Hall DE, Kim G, Koo YEL, Woolliscroft MJ, Sugai JV, Johnson TD, Philbert MA, Kopelman R, Rehemtulla A, Ross BD. Vascular targeted nanoparticles for imaging and treatment of brain tumors. Clin Cancer Res. 2006;12:6677-6686.

[105] Liu XZ, Li G, Su ZG, Jiang ZM, Chen L, Wang JF, Yu SZ, Liu ZL. Poly(amido amine) is an ideal carrier of miR-7 for enhancing gene silencing effects on the EGFR pathway in U251 glioma cells. Oncol Rep. 2013;29:1387-1394.

[106] Zhang PC, Hu LJ, Yin Q, Feng LY, Li YP. Transferrin-modified c RGDfK -paclitaxel loaded hybrid micelle for sequential blood-brain barrier penetration and glioma targeting therapy. Mol Pharm. 2012;9:1590-1598.

[107] Zhan CY, Gu B, Xie C, Li J, Liu Y, Lu WY. Cyclic RGD conjugated poly(ethylene glycol)co-poly(lactic acid) micelle enhances paclitaxel anti-glioblastoma effect. J Control Release. 2010;143:136-142.

[108] Zhan CY, Li B, Hu LJ, Wei XL, Feng LY, Fu W, Lu WY. Micelle-based brain-targeted drug delivery enabled by a nicotine acetylcholine receptor ligand. Angew Chem-Int Edit. 2011;50:5482-5485.

[109] Huang YK, Liu WC, Gao F, Fang XL, Chen YZ. c(RGDyK)-decorated pluronic micelles for enhanced doxorubicin and paclitaxel delivery to brain glioma. Int J Nanomed. 2016;11:1629-1641.

[110] Kuroda JI, Kuratsu JI, Yasunaga M, Koga Y, Saito Y, Matsumura Y. Potent antitumor effect of SN-38-incorporating polymeric micelle, NK012, against malignant glioma. Int J Cancer. 2009;124:2505-2511.

[111] Kuroda J, Kuratsu J, Yasunaga M, Koga Y, Kenmotsu H, Sugino T, Matsumura Y. Antitumor effect of NK012, a 7-ethyl-10-hydroxycamptothecin-Incorporating polymeric micelle, on U87MG orthotopic glioblastoma in mice compared with irinotecan hydrochloride in combination with bevacizumab. Clin Cancer Res. 2010;16:521-529.

[112] Zhao M, Liang C, Li AM, Chang J, Wang HJ, Yan RM, Zhang JJ, Tai JL. Magnetic paclitaxel nanoparticles inhibit glioma growth and improve the survival of rats bearing glioma xenografts. Anticancer Res. 2010;30:2217-2223.

[113] Cheng Y, Dai Q, Morshed RA, Fan XB, Wegscheid ML, Wainwright DA, Han Y, Zhang LJ, Auffinger B, Tobias AL, Rincon E, Thaci B, Ahmed AU, Warnke PC, He C, Lesniak MS. Blood-brain barrier permeable gold nanoparticles: an efficient delivery platform for enhanced malignant glioma therapy and imaging. Small. 2014;10:5137-5150.

[114] Aparicio-Blanco J, Martin-Sabroso C, Torres-Suarez A-I. In vitro screening of nanomedicines through the blood brain barrier: a critical review. Biomaterials. 2016;103:229255. 